\title{
The 1993 EITC Expansion and Low-Skilled Single Mothers' Welfare Use Decision
}

\author{
Hau Chyi * \\ Preliminary Draft
}

September 19, 2007

\begin{abstract}
Previous studies on low-skilled single mothers generally focus on the binary decisions of either welfare use or work. However, work among welfare participants has increased steadily since the mid 1990s. This study estimates the joint probability of the two decisions using a bivariate probit model. I investigate the role of the 1993 EITC expansion on the decline of welfare caseloads. Using monthly welfare use and work information from the Study of Income and Program Participation, I find that the 1993 EITC expansion has at least the same effect on reducing welfare use as the welfare reform initiatives, in particular, welfare time limits. Moreover, the elasticity estimates indicate that single mothers, especially those who were not employed and dependent solely on welfare before the expansion, were more responsive to the EITC expansion than to welfare time limits. Finally, the increase in work among welfare participants is due to the relative ineffectiveness of the policies in reducing the net population of those who are on welfare and work simultaneously.

JEL Classification: I3, J13, J22
\end{abstract}

*The author can be reached at: hchyi@wisc.edu. The author wants to thank Meta Brown for her guidance and encouragement. The author is grateful for valuable suggestions from John Karl Scholz and John Kennan. The author would also like to thank to Bruce Hansen, Jim Walker, Binzhen Wu, and all participants of the University of Wisconsin Public Workshop. All errors are the author's own. 


\section{Introduction}

The 1990s saw radical changes in means-tested transfer programs in the U.S. In one such change, the 1996 Personal Responsibility and Work Opportunity Act (PRWORA) replaced the long-lived Aid to Families with Dependent Children (AFDC) program with the Temporary Aid to Needy Families (TANF) program. By introducing a sixty-month time limit and a work requirement for eligibility, ${ }^{1}$ the TANF ended cash assistance as an entitlement of needy families in the U.S. An equally drastic change was the expansion of the Earned Income Tax Credit (EITC) program in 1993. In the 1990s, the maximum tax credit increased by more than fourfold and the amount spent on the EITC by the federal government grew from 9.6 billion (in 1999 dollars) in 1990 to 32.2 billion dollars in 1999. During the same time and in conjunction with an unprecedented expansion in the economy, total welfare caseloads decreased to 2.3 million families in 1999 from 4.1 million in 1990. Focusing on lowskilled single mothers, Figure 1(a) depicts the historical trends of welfare use and employment using 1989 to 2000 data drawn from Survey of Income and Program Participation (SIPP). ${ }^{2}$ As we see, while employment increased by about $30 \%$ (from $45 \%$ to $58 \%$ ) since 1995 , welfare use declined sharply by about $70 \%$ (from $34 \%$ to $11 \%$ ) among this group of low-skilled single mothers.

Aimed at improving work incentives among low-income families, the EITC is a U.S. federal program that provides wage subsidies to working families. To be eligible for the EITC program, a tax filer must have at least one child younger than eighteen years old living with the family. The EITC program provides eligible income tax filers with a tax credit based on three parameters: a phase-in range, a maximum credit, and a phase-out range. The tax credit increases with an eligible filer's earnings while such earnings are in the phase-in range. Similarly, the tax

\footnotetext{
${ }^{1}$ Under certain conditions, states can grant exemptions from the time limit requirement, so long as the total number of such exemptions does not exceed $20 \%$ of the state welfare caseload.

${ }^{2}$ The sample includes all single mothers who received no more than twelve years of schooling and whose children are no older than eighteen years old. They are hence potentially eligible for both the EITC and welfare programs. Employment is defined as having reported more than 10 hours of work in a week in the previous month.
} 
credit decreases with earnings when an eligible filer's earnings are in the phase-out range. When an eligible filer's earnings are between the two ranges, the tax credit will be given at the maximum credit level. Using the same table prepared by Hotz and Scholz (2003), Table 1 repeats the EITC program parameters since it was first launched in 1975.

In 1993, the EITC program was expanded. Before 1991, EITC did not distinguish among families based on number of children in the family in the calculation of the tax credit. After 1993, families with two or more children receive a significantly large tax credit than those with one child. In 1994, families with two or more children could receive a maximum EITC credit that was $24 \%$ more than that could be received by their one-child counterparts $(\$ 2,528$ as opposed to $\$ 2,038)$. This gap was widened to $33 \%$ in 1995 (\$3,110 to $\$ 2,094)$, and then to $65 \%$ in 1996 (\$3,556 to $\$ 2,152)$. Since 1996, the gap is unchanged, but the credit levels are adjusted according to the price level. Families with more than one child also enjoy a higher phase-in rate, longer phase-in range, and a higher phase-out rate, than their one-child counterparts. ${ }^{3}$

Numerous studies have focused on the effects of the EITC program on an individual's behavior in a variety of areas ranging from work to fertility (see Hotz and Scholz (2003) for a review). However, not many studies focus on the possible effect of the EITC program on single mothers' welfare use. Studies on welfare caseload have mainly focused on the effects of state welfare waivers and other initiatives in the welfare reform, such as benefit reduction or welfare time limits (for example, CEA (1997, 1999) and many studies that followed, see a review by Ochel (2004)). As late as 2003, Grogger argues in his research that it "is the first study to provide direct estimates of the effects of the EITC on welfare use."

This research is different from previous studies in the following aspects. First, I

\footnotetext{
${ }^{3}$ Measured by earnings, more than three quarters of low-skilled working single mothers in SIPP are eligible for EITC. Nationally, about 80 to $85 \%$ of the eligible families filed the credits, with an average received credit at $\$ 1,700$ (see http://www.brookings.edu/es/urban/eitc/dataguide.htm). Note that credits received and filed are generally not the same. About $13 \%$ of the filed credits are used to offset the tax owed. See http://taxpolicycenter.org/TaxFacts/papers/irs_eitc.pdf for a further discussion on the assessing methodology.
} 
incorporate single mothers' simultaneous decisions of welfare use and work through estimating the joint probabilities of four states: (no work, no welfare), (work, no welfare), (no work, welfare), and (work, welfare) using a bivariate probit model.

The conventional wisdom is that welfare participants do not work. As a result, studies on poor families mostly focus on the binary decisions (i.e., marginal probabilities) of either welfare use or work. Using the data from SIPP, however, I find that, although the absolute number of welfare caseloads is decreasing, the ratio of welfare participants who have reported ten or more hours of work in any given month has increased form 8\% in 1990 to $40 \%$ in 2000 (see Figure 1(b)). Hence it is of interest to investigate the compositional change among the four states due to policy changes. Such investigation can not be shown using the marginal probabilities of either welfare or work.

Second, using the identification strategy developed in Hotz, Mullin, and Scholz (2005), I contribute to welfare caseloads study by investigating the implication of the expansion of the EITC program. ${ }^{4}$ Compared to many welfare reform initiatives that put restrictions on welfare participants' behavior, the EITC motivates participants to leave welfare through a direct increase in their real wage and an indirect accumulation in work experience. As a result, understanding the relative effectiveness of different initiatives to reduce welfare caseloads may give us further insight into designing better alternatives to move people from welfare to work.

The population I examine are single mothers who have received twelve years or less of schooling, and whose youngest child no older than 18 years old, which makes them potentially eligible for both welfare program and the EITC. I focus on this particular group of mothers because they comprise the majority of welfare recipients. The information used in this study is from SIPP during the period of

\footnotetext{
${ }^{4}$ The restriction of the identification strategy is that I can only assess the effectiveness of the 1993 EITC expansion on families with more than one child by the different treatments from families with one child. However, the EITC program has been steadily expanded since 1986. It would be of interest to evaluate the overall effectiveness of the EITC program by comparing eligible families who were affected (mostly have children) to similar families that were not eligible (such as childless single women).
} 
1989 to 2000. SIPP provides detailed information on monthly welfare use and work decisions. Monthly information is essential to estimating the joint probabilities, as annual data surveys such as March Current Population Survey or Panel Study of Income Dynamics can make it appear that the annual welfare and work decisions are made jointly.

The estimates of the bivariate probit model indicate that the 1993 EITC expansion did not significantly differ the decisions of single mothers with two or more children from their one-child counterpart until 1996. This corresponds to the steady increase, which began in 1993, in the EITC "generosity" gap between families with one child and those with two or more children. During the same period, welfare time limits only affect single mothers whose youngest child is below five years old. Taking into account welfare reform initiatives, state fixed-effect, business cycle factors, as well as a set of individual characteristics, the 1993 EITC expansion explains about 2.6 percentage points of the decrease in the welfare use after 1993. At the same time, welfare time limits explains about the same magnitude of the decline of welfare caseloads.

The elasticity estimates show that the absolute values of the EITC elasticities on four alternatives are all greater than those of the welfare time limits elasticities. This indicates that single mothers react to the EITC expansion more strongly than they do to welfare time limits. Also, of all single mothers, those who were not employed and thus solely dependent on welfare before the expansion of the EITC were most responsive to the EITC expansion.

The estimates also suggest that both policy changes significantly increase a lowskilled single mother's likelihood of relying solely on work without welfare, while it almost uniformly decreases the likelihood of a mother's reliance solely upon welfare, or a combination of welfare and work. Notably, although the sign is negative, policy changes seem to have minor effects on those welfare participants who had been working, both in terms of the magnitude and the significance of the estimate. Hence, it can be inferred that the increase in work among welfare participants is due to the relative ineffectiveness of the policies on reducing the net population of those who 
simultaneously are on welfare and work.

However, estimation results also suggest that policy changes have their strongest effects on reducing welfare use not among the youngest mothers (defined as being in their 20s in the mid 1990s), but among the mothers in their 30s in the mid 1990s. Finally, although a bivariate probit model essentially treats the sample as crosssectional, these estimates are fairly stable under a linear probability specification that incorporates the individual fixed-effects.

The structure of this study is as follows: Section 2 provides a review of the literature on the effects of the EITC and welfare reform on low-skilled single mothers' work and welfare use decisions; Section 3 investigates the strategies used to identify the effects of the expansion of the EITC program, as well as the needed identification assumptions; Section 4 describes the empirical specification of the baseline estimator, a bivariate probit model for a single mother's welfare use and work decisions; Section 5 describes the sample used in this study; Section 6 discusses the estimation results; and Section 7 gives the conclusions.

\section{Review}

Using a static consumption-leisure model, it is straightforward to show that the EITC program provides an unambiguously positive effect on single mothers' labor force participation (Hotz and Scholz (2001)). Numerous studies provide empirical support for this prediction (see Table 3).

Meyer and Rosenbaum (2001) focus on cross-sectional samples. ${ }^{5}$ They use a probit model of a single mother's work decision derived from a static economic

\footnotetext{
${ }^{5}$ The samples consist of female heads of households between 19 to 44 years old from March CPS during 1984 and 1996. They study the effects of changes to the EITC and other taxes, as well as pre-reform welfare policies on a single woman's work decision. Their primary focus is on the effects of changes in monetary incentives. In their research, work is defined by whether a single mother worked last week or whether she worked at all last year.
} 
model. Their primary specifications compare single women with children to those without a child. The authors find that the EITC is the most important contributor to the increase of labor force participation during the sample period, with a small share of the increase attributable to changes in welfare policies, such as benefit reduction and welfare waivers. ${ }^{6}$

Hotz, Mullin, and Scholz (2005) study the effect of the EITC on single mothers' labor force participation. They use a longitudinal sample drawn from California's administrative data on welfare program participation, employment and earnings between 1987 and 2000. ${ }^{7}$ They estimate the effect of the EITC program using a difference-in-difference approach by comparing the employment status of families with more than one child to families with one child before and after the 1993 EITC expansion. $^{8}$ Conditional on year, county and individual fixed-effects, their linear probit model of work suggests that the EITC explains a significant portion of the increase in the employment of California's single mothers who have ever been on welfare $^{9}$

Studies of welfare caseloads have mainly focused on the effects of changes in state welfare waivers and other welfare reform initiatives, such as benefit reduction or welfare time limits (for example, CEA $(1997,1999)$ and many studies that followed, see a review by Ochel (2004)). Surprisingly, not many studies focus on the possible effect of the EITC program on single mothers' welfare participation (as distinct from

\footnotetext{
${ }^{6}$ In another specification, the also compare the difference between single mothers with two or more children and (i) single women with no offspring (or with their youngest child older than eighteen) and (ii) single mothers with only one child. The rationale for this comparison is that the first group is not eligible for the EITC (nor AFDC), and the second group faces a different EITC scheme since the 1993 expansion. The results are similar.

${ }^{7}$ In their sample, each single mother is observed consecutively for four years. Work is defined as either having reported earnings to the UI system in a given year or having earnings exceeding $\$ 500$ and $\$ 1,000$ in the year.

${ }^{8}$ As families with two or more children enjoy a much larger increase in the EITC that they can earn beginning with the 1993 expansion than their one-child counterparts, the effect of the EITC, holding everything else constant, should be greater for the former group.

${ }^{9}$ Furthermore, using tax data, they find that EITC-claiming behavior mirrors the employment pattern in the data. Also, there is no significant difference in tax filing behaviors between families with two children and families with more than two children. These findings reinforce the validity of their identification strategy.
} 
labor force participation). As late as 2003, Grogger argues in his research that it "is the first study to provide direct estimates of the effects of the EITC on welfare use." The main focus of Grogger (2003) is on the effects of welfare time limits and the remaining welfare reform initiatives, as well as the EITC on welfare participation. The dependent variables include welfare, employment, labor supply, earnings, and income among female headed families. He uses a cross-sectional sample from the March CPS survey between 1979 and 2000.

The effects of welfare time limit are estimated using a difference-in-difference approach developed in Grogger and Michalopoulos (2003). ${ }^{10}$ The treatment and control groups are families with their youngest child below thirteen years old and families with their youngest child above thirteen years old, respectively. The rationale is that the younger the youngest child is in a family, the more valuable the insurance purpose of the welfare program will be to the family. Facing the new, sixty-month time limit, ${ }^{11}$ single mothers with younger children will react to to the time limit more strongly than families that have their youngest child above thirteen, as they are approaching the welfare ineligibility age (eighteen years old) and will be ineligible for welfare benefits before or at the point that the time limit would affect them.

As for the effects of the EITC program, Grogger uses the maximum credit as a representation of the overall generosity of the EITC. The effects of the EITC expansion on female heads' different outcomes are estimated by using the differential treatments in the maximum credits on families with one child and those with more than one child. He finds that, the increase of the EITC maximum credit between 1993 and 1999 explains $15.8 \%$ of the decline in welfare use during this period, while about one-eighth of the decline can be attributed to welfare time limits. Based on his research, he concludes that the EITC has a larger effect on reducing single

\footnotetext{
${ }^{10}$ Grogger and Michalopoulos (2003) study the effect of welfare time limits using data from a randomly designed experiment in Florida's Family Transition Program.

${ }^{11}$ Not all states adopted a time limit of sixty months. See Table 2 for the exact length in each state. In this study I use the exact lengths and dates listed in Table 2 to construct all time-limit variables.
} 
mothers' welfare participation than do welfare time limit.

An immediate concern to Grogger (2003) is that, as the EITC parameters are adjusted annually, and are also correlated with the number of children the applicant has, the linear structure adopted by Grogger may suffer from a near-multicollinearity problem. ${ }^{12}$ Grogger adopts a difference-in-difference framework where the outcome is a linear function of the level of the maximum EITC credit and the interaction term between the credit and age of the youngest child. Further, he also includes in the explanatory variables the year fixed-effects and the number of children a family has. Although the credit and the interaction terms themselves are not perfectly linear in year and the number of children, they are very closely related. If such near multicollinearity does exist, the estimates may be imprecise due to large standard errors.

I attempt to address this issue in two ways. First, to study the linear relationships between these variables, I estimate an OLS regression of the real maximum credit on single mother's number of children and year dummies (see Table 4). The estimation indicates that both $R^{2}$ and $\bar{R}^{2}$ are at $94.6 \%{ }^{13}$ The $R^{2}$ and $\bar{R}^{2}$ of regressing the interaction term on the same set of explanatory variables are both at $88 \%$ (Table 5). Both of the two estimations suggest a near-linear relationship. Moreover, when similar multicollinearity tests are applied to other explanatory variables used in Grogger (2003), none of the $R^{2}$ of the estimations are more than $10 \%$ (the results are not shown here).

Second, of Grogger (2003)'s regressions of the effect of the EITC maximum credit on six outcomes mentioned above, only its effect on welfare use (identified by the interaction between the maximum credit and age of the youngest child) is significant. ${ }^{14}$

\footnotetext{
${ }^{12}$ Also, the variation in the magnitude of the maximum credit will not be able to capture the full impact of the EITC on single mothers' behaviors. This is due to the fact that the received credit (hence the effective EITC tax rate) is endogenous to an applicant's work decision and not all applicants for the EITC receive maximum credit.

${ }^{13}$ The sample is constructed by using an annual sample of single mothers by using National Longitudinal Survey of Youth 79 under similar conditions to that constructed by Grogger (2003).

${ }^{14}$ Also significant are the coefficients of the maximum credit on employment, weeks worked, and earnings.
} 
As one of the typical symptoms of multicollinearity includes that the coefficients of the variables in question are generally not statistically significant, Grogger's outcomes seem to suggest the existence of multicollinearity and raise an issue of identification. In fact, when I use the EITC identification strategy of Hotz, Mullin, and Scholz (2003) and estimate similar regressions, the estimated effects of the EITC are significant for most of the dependent variables (results not shown here).

A different consideration is that, in theory, a single mother's welfare use and work decisions are correlated, as she decides jointly her work and welfare use decisions. Hence, the marginal probabilities of welfare and work form a system of simultaneous equations. In principle, if we do not take into account the effect of one decision (say, work) when investigating the other (in this case, welfare use), the estimator will be biased due to the omitted variable problem.

To this end, Meyer and Rosenbaum (2001)'s study of female household heads' work assumes that all non-working single mothers participate in welfare, and also construct a probability of participating in welfare given work as one of the explanatory variables. Hotz, Mullin, and Scholz (2003) use a sample of single mothers who received welfare at some point in the sample period to study the effect of the EITC on work. As a result, it can be viewed as the work probability given use of welfare. On the other hand, Grogger (2003) treats work and welfare use as two independent decisions, and does not control the likelihood of one decision in estimating the probability of the other decision.

Assuming that single mothers make two binary decisions about work and welfare use, there are four possible outcome states, (no work, no welfare), (work, no welfare), (no work, welfare), and (work, welfare). However, if relatively few single mothers choose to be on welfare and work simultaneously in reality, the bias, even if it exists, will be small. As a result, it is important to examine the extent to which the simultaneity issue exists in the data.

As eligibility for AFDC is determined monthly, it is also possible that the monthly decisions of welfare use and work are disjointed, yet the annual welfare and work 
decisions reported in March CPS or PSID can look like that they are made jointly. ${ }^{15}$ Unlike March CPS or PSID, SIPP has a rich set of histories on each individual's monthly hours of work and AFDC receipts information, dating back to as early as 1989. As a result, I can use SIPP to investigate the simultaneity nature of single mothers' decisions. ${ }^{16}$ If a significant number of single mothers in SIPP chose to be on welfare and work simultaneously, ignoring the joint nature is likely to lead to a serious bias.

Figure 1(b) shows the conditional distribution of the mean status of single mothers' work given welfare status from 1989 to 2000. The sample comes from all SIPP single mothers who received twelve years or less schooling and whose youngest child is no older than eighteen years old (hence qualify for both the EITC and the welfare program). As the eligibility of welfare system, to a large extent, is determined by an individual's work status in the preceding month, work is defined as having reported at least 10 hours of work per week in the previous month. It should be noted that the statistics for the year 2000 are not as accurate as those in the previous years due to its relatively small number of sample observations.

The most significant phenomena shown in the figure is the large increase since 1995 of welfare participants who chose to work. In 1989 this ratio was at about $8 \%$. It slowly increased to about $11 \%$ in 1995 and then jumped to about $20 \%$ in 1996 . In 2000 about $40 \%$ of all welfare participants were working for at least 10 hours per week. At the same time, the proportion of work among non-participants remains fairly stable at about $60 \%$. Combined with the fact that there is a 10 percentage points increase in the overall employment and a 20 percentage points decrease in the welfare caseloads during the same period of time (see Figure 1(a), this shows a significant compositional change in the four states of decisions among single mothers. 17

\footnotetext{
${ }^{15}$ Thanks to Professor John Karl Scholz for pointing out this issue.

${ }^{16}$ I combine 1990, 1991, 1992, 1993, and 1996 panels to form the sample. See a further discussion in Section 5.

${ }^{17}$ One would expect that, the ratio of (work, welfare) decreases as we restrain the definition of work. If work is defined as having worked for more than 120 hours a month (i.e., 30 hours per week), welfare participants who worked in the previous month decrease from $16 \%$ to $9 \%$.
} 


\section{Identification}

To identify the effect of the 1993 EITC expansion I follow the strategy proposed by Hotz, Mullin, and Scholz (2006). As families with more than one child enjoy a much more generous EITC scheme than their one-child counterparts, we can consider families with one child as the control group and those with more than one child as the treatment group, assuming that the decision making processes of the two groups are similar in the face of a similar socioeconomic environment. Hence, a difference-indifference (DD) approach can be used to estimate the effect of the EITC expansion. Under this DD approach, the identification comes from a comparison of differences in behaviors between these two types of families before and after the EITC expansion. ${ }^{18}$

For the effects of welfare reform, I follow Grogger and Michalopoulos (2003) and Grogger $(2003,2004)$ and focus mainly on welfare time limits. I follow Grogger's identification strategy, where he estimates the effect by using a difference-indifference approach, where the first source of variation comes from the time variations in the states' adopting the new time limits. ${ }^{19}$ The second source of variation comes from the fact that families with youngest child over thirteen will not be affected by the 60-month time limit. I further separate families who are likely to be

Also, one may worry about the accuracy of the welfare office in keeping track of applicants' work status. In the GAO 1996 report on welfare waiver implementation, it is mentioned that keeping accurate records of welfare eligibility was the main goal of welfare offices.

${ }^{18}$ Since Hotz, Mullin, and Scholz include a mother's fixed-effect in the probability model, only mothers who have changed status during the sample period are included in their estimation. As a result their identification comes from families that change status from one child to two or more children or vice versa.

A different way to estimate the effect of the EITC program is by using the annual variation in the tax rates. Assuming that the effect of the effective EITC tax rate is continuous, Meyer and Rosenbaum (2001) study the effect of the EITC program on single mothers' work decisions, while Grogger (2003) focuses on the welfare use decision among single mothers. As the effective EITC tax rate is determined by how much a single mother earns in labor income in a given year, it is endogenous. Meyer and Rosenbaum (2001) calculate an "expected tax" that a woman would pay in a given state and year with a given family composition and ages of children, derived by integrating over distributions of single mothers' wages and hours. On the other hand, Grogger (2003) uses the different levels of maximum EITC benefits faced by families with different numbers of children.

\footnotetext{
${ }^{19}$ Fourteen states included a time-limit in their waivers before 1996, while all states were required to have welfare time limits after 1996. Table 2 sets out the information on state waivers and TANF. Note that Michigan and Illinois use state funds to pay for welfare benefits after participants reach sixty months. As a result, they essentially have no time limit.
} 
affected by the limits into three groups: under five years old, between five and ten years old, and between ten and thirteen years old.

Given that a work requirement is often combined with other initiatives that may have mixed incentives (for example, a lower effective tax rate on earning), I use whether a state has implemented a work requirement on welfare participants to represent the remainder of the initiatives other than welfare time limits. To estimate the composite effects of the whole bundle of initiatives that come with work requirement, I rely solely on the time variation when the state implemented their versions.

Further, I include year and state fixed effects to control for the business cycle and unobserved state-level characteristics that are unchanged over time. By the use of these dummy variables, I essentially control for effects from concurrent events that are neutral to the age of the youngest child and the number of children in a family.

In order to ensure that the DD estimator identifies the effect of the EITC expansion alone, one requirement is that the effects of concurrent events are invariant with the number of children a single mother has. This may be the most problematic assumption. For example, if a work requirement has different effects on families with different number of children, it will also be captured in the DD estimator. One way to test this assumption is to adopt a difference-in-difference-in-difference (DDD) approach that allows a work requirement imposed by welfare reform to interact with the EITC expansion. Although ten states have included a work requirement in their state waivers, I do not have enough variation in the data to test whether the effect of the work requirement is invariant with the number of children of a single mother.

Also, one may be concerned about the effects of policy changes on a mother's marital status and childbearing decisions. The expansion of the EITC changes the effective marginal tax rates on labor income. On the one hand, single mothers who have little or no labor income can receive a marriage subsidy by marrying a similarly situated man, given that their combined income is still in the EITC phase-in range. On the other hand, couples may choose to dissolve their marriage because staying 
together is financially disadvantageous. ${ }^{20}$ One solution to this problem which was used by Keane and Wolpin (2006) is to combine marriage, childbearing, work, and welfare use decisions together in a dynamic structural model. For simplicity however, I treat these decisions as exogenous in this research.

Furthermore, one crucial assumption of a valid difference-in-difference estimator is the parallel trend between treatment and control groups. That is, the trend of the treatment group would have been the same as the control group had the treatment group not experienced the policy change. This assumption can be checked by investigating whether there is a difference in the behaviors between the treatment and control groups before the policy change took place. If there is no pre-expansion difference between these two groups, we will have more confidence in the assumption. To do so I use the interaction term between individual year and two-and-more children indicators to estimate the effects of the EITC expansion. It the parallel trend assumption is correct, the estimates of the interaction terms between the number of children indicator and the year indicators before 1993 should be insignificant.

\section{A Bivariate Probit Model of A Single Mother's}

\section{Welfare Use and Work Decisions}

Assuming a single mother chooses simultaneously whether to be on welfare $(W)$ and to work $(H)$ in each period, there are at least four alternatives: (No Work, No Welfare), (Work, No Welfare), (No Work, Welfare) and (Work, Welfare).

To estimate the joint probability of a mother's simultaneous decisions of welfare

\footnotetext{
${ }^{20}$ Using a linear probability of marriage decision of single mothers shows that the expansion is associated with an increase in a mother's likelihood to marry by a small, yet significant, $2.4 \%$. Also, as the expansion sharply increases the credit gap between one-child families and those with two or more children, single mothers with one child may want to have another child. Estimates of the childbearing decision among low-income mothers show that the expansion does have a significant, but small, positive-effect.
} 
use and work, I assume it can be described by a bivariate probit model. Following the standard argument of a probit model, the stochastic (unobserved) part of ( $W$, $H),\left(W^{*}, H^{*}\right)$, is continuous and can be written as:

$$
\begin{aligned}
W_{i s t}^{*} & =\beta_{0}+\beta_{1} \sum_{l=1989 \_01}^{2000 \_12} D_{i, 2+\text { kids }, l} D_{l}+\sum_{l=1989 \_01}^{200 n_{1} 12} \sum_{j=1}^{3} \beta_{2 j} D_{i, j, l} D_{i, \text { timelimit }, l}+ \\
& +\sum_{l=1989 \_01}^{2000 \_12} \sum_{k=1}^{9} \beta_{3 k} D_{i, \mathrm{kids}=k, l}+\sum_{s=1}^{S} \beta_{4 s} D_{i s t}+\sum_{y=1989}^{2000} \beta_{5 y} D_{y}+\beta_{6} \sum_{l=1989 \_01}^{2000_{1} 12} D_{i, \text { timelimit }, l} \\
& +\beta_{7} \sum_{l=1989 \_01}^{2000_{1} 12} D_{i, \text { workreq }, l}+\gamma X_{i s t}+\epsilon_{i}^{W},
\end{aligned}
$$

where:

- $t$ indicates the year-month dummy variable. I use SIPP monthly information from January of 1989 to December of 2000.

$-D_{i, 2+\mathrm{Kids}, t}=1$ if $i$ has more than one child.

- $D_{l}$ is the year-month dummy variable. $D_{l}=1$, if $t=l$.

- $D_{i, j, t}=1$ if $i$ 's youngest child is under five years old $(j=1)$, between five and ten years old $(j=2)$, and between ten and thirteen years old $(j=3)$ in $t$, respectively.

$-D_{i, \text { timelimit }, t}=1$ indicates $i$ lives in a state with some form of time limits in $t$.

- $D_{i, \mathrm{kids}=k, l}$ is the dummy for number of kids. $D_{i, \mathrm{kids}=k, t}=1$, if $i$ has $k$ kids in $t$.

- $D_{\text {ist }}$ is the state dummy to control for unobserved state generosity towards poor families. $D_{i s t}=1$, if individual $i$ lives in state $s$ in $t$.

- $D_{y}$ is the year dummy. I control business cycle factor up to the year level.

- $D_{i, \text { workreq, },}$ is the dummy for work requirement. $D_{i, \text { workreq }, l}=1$ if individual $i$ lives in a state with work requirement in year $t$.

- $X_{\text {ist }}$ includes mother-specific characteristics, including age, years of schooling, age of youngest child, income other than earned and AFDC benefit, ${ }^{21}$ and race indictors, including black and hispanics dummies.

\footnotetext{
${ }^{21}$ All monetary terms are deflated into real 2000 dollars by Personal Consumption Expenditure Deflator, PCED.
} 
$-\epsilon_{i}^{W}$ is the random error, which we assume to be distributed normally.

The latent variable $H^{*}$ can be defined similarly.

We have:

$$
\begin{aligned}
& W=\left\{\begin{array}{ll}
1 & \text { if } W^{*}>0 \\
0 & \text { otherwise }
\end{array}\right. \text {, and } \\
& H= \begin{cases}1 & \text { if } H^{*}>0 \\
0 & \text { if otherwise }\end{cases}
\end{aligned}
$$

Assume the two random errors $\left(\epsilon_{i}^{W}, \epsilon_{i}^{H}\right)$ can be described by a bivariate normal distribution. That is:

$$
\left(\begin{array}{c}
\epsilon_{i}^{W} \\
\epsilon_{i}^{H}
\end{array}\right) \sim \mathrm{N}\left\{\left(\begin{array}{l}
0 \\
0
\end{array}\right),\left(\begin{array}{ll}
1 & \rho \\
\rho & 1
\end{array}\right)\right\}
$$

where $\rho$ is the correlation coefficient between a mother's welfare use and work decisions. Based on the observation from Figure 1, we can expect $\rho$ to be negative. To further exclude the effects of explanatory variables of work from welfare use, I also include in Equation (2) two additional variables that affect a single mother's likelihood of work but not her welfare use. First, I include the annual AFDC effective tax rate on earned income calculated by Terra, Sanders, and Smith (1999), because given two mothers with the same characteristics, the one who lives in a state with higher effective tax rate on earned income should be less likely to work than the one who lives in a low tax rate state. Second, I also include the expected probability of work estimated from a sample of females who have no child. The idea is that this predicted probability of work, even estimated from a population who are not eligible for welfare, should be correlated with work decision of those mothers who are eligible for welfare. However, given that the population are not eligible for welfare, the estimated probabilities should be uncorrelated with the welfare use decision. ${ }^{22}$ A final issue is that, since I have repeated observations on a same mother, I control for intra-class correlation to obtain a robust standard deviation. This completes the econometric structure of the estimation.

\footnotetext{
${ }^{22}$ Using the constructed sample of unskilled single mothers who are eligible for welfare, the estimated likelihood of work is only correlated with welfare use at a $10 \%$ confidence level.
} 
In this specification, $\beta_{1}$ captures the effect of the EITC program on welfare use among single mothers. The identification comes from comparing the pre- and postEITC expansion differences between families who have only one child and those who have more than one child. Also, $\beta_{2 j}, j=1,2,3$ captures the effect of welfare time limits on single mothers who have children that are below five, between five and ten, and between ten and thirteen years old, respectively. This is identified by comparing the difference in pre- and post-time limits behaviors between single mothers whose youngest child is below thirteen years old and those whose children are above thirteen. To identify both $\beta_{1}$ and $\beta_{2 j}$ together I rely on the fact that the two policies have different target groups. Time limits only affect single mothers who have children that are below thirteen years old, while the expansion of the EITC affects families with two or more children. As a result, the two policy effects entered into the specification additively.

$\beta_{4 s}$ and $\beta_{5 l}$ capture the possible state $(s)$ and year $(l)$ fixed effects that are unobserved by econometricians. For example, a state that set a time limit before PRWORA (observed variable), may also be less generous to its support of lowincome families (unobserved variable), and in turn, poor families residing in this state are also less likely to be on welfare. Another important issue regarding welfare use is the effect of business cycles. For example, it is well known that the recession in the early 1990s was an important cause of the sudden surge in welfare use during that same period of time.

Since most state welfare programs are operated at the county level, a better control than state fixed-effect is to use county fixed-effect, as in Hotz, Mullin, and Scholz (2005). Because the data from which I draw my sample (SIPP) does not provide county information, however, I am not able to control for the county socioeconomic conditions. $^{23}$ Another issue is that, with the existence of an unobserved individual fixed-effect, the estimation of the probabilities based on observed factors is not

\footnotetext{
${ }^{23}$ I also estimate the model using a sample of single mothers drawn from NLSY 79, which enables me to control for the county-level socioeconomic factors that may affect a single mother's decisions. I control for unemployment rate, proportion of female headed households to total number of households, per capita transfer payments, and county poverty rate among female heads. But the results are similar to those reported in Section 6 .
} 
consistent. However, due to the nonlinear nature of the bivariate probit model, we cannot eliminate the individual fixed-effect by subtracting the individual mean from raw data, as is typically done in a linear probability specification. As a result, the bivariate probit model is essentially treating the sample as cross-sectional.

The inability of controlling for the unobserved individual characteristics is an important disadvantage of using a non-linear probability model. A linear (binary) probability model with individual fixed effect, however, is not suitable for the purpose of this study, which involves the joint nature of welfare use and work decisions. In Section 6.2, I compare the estimates between the joint probit model and linear probability model with fixed effect to evaluate the seriousness of unobserved individual heterogeneity. ${ }^{24}$

\section{Data and Sample}

The sample used in this research comes from pooling the monthly information of the SIPP 1990, 1991, 1992, 1993, and 1996 panels. Given the different lengths of the SIPP panels, the sample spans over the years from 1989 through 2000, which includes five years before and seven years after the expansion of the EITC program in 1994. The population I examine in this study includes low-skilled single mothers who are potentially eligible for both the EITC and the welfare programs. A lowskilled single mother is defined as having received twelve years of schooling or less. One of the eligibility requirements of both welfare and the EITC programs is that a mother's youngest child be no older than eighteen years old. I define my sample accordingly. Note that due to the wave structure of the SIPP, I have fewer numbers of observations in 1989 and in 2000.

Note that SIPP is known for at least two potential issues that may have potential

\footnotetext{
${ }^{24}$ Given the relatively short panel lengths of different SIPP panels, the effects are mostly estimated through comparisons between mothers from different panels. This is one disadvantage of the SIPP compared to long panels such as NLSY 79.
} 
implications to the research in interest. First, the seam bias, i.e., participants report the same information for every month in a wave, may lead us to erroneously identify the effect by the information from reference month one. Given that I have detailed monthly information on dates of state waiver program and TANF implementation, I use monthly information. The seam bias is controlled by following Blank and Ruggles (1996), where I add an indicator variable for reference month one. Also, it should be noted that SIPP participants tend to under-report their income sources from programs.

Figure 1 depicts the historical trends of welfare use and work (defined as having reported working for ten hours or more in the previous month) among my target group. Table 6 lists the weighted sample descriptives. ${ }^{25}$ There are 145,291 mothermonths (observed from 8,792 mothers distributed across the five SIPP panels). The mean welfare use and work are at $18 \%$ and $52 \%$, respectively. More than half of the sample mothers in each year have two or more children. In particular, about $57 \%$ of the sample mothers before 1995 had two or more children, but the same ratio increased to $77 \%$ after 1995. As discussed in Section 3, one of the assumption is that policy changes are uncorrelated with a single mother's childbearing decision. The sample statistic seems to suggest that the EITC expansion is associated with an increase in the likelihood of having two or more children among low-skilled single mothers. However, I do not deal with this issue in this study (see also footnote 20).

For the welfare reform initiatives, about $33 \%$ of the sample reside in a state with some form of work requirements. Also, $23 \%$ of the sample mothers have a youngest child younger than five years old and reside in a state with some form of time limits. The same ratios for sample mothers who have a youngest child aged between five and ten years old and between ten and thirteen, are at $8 \%$ and $2 \%$, respectively.

As for their individual characteristics, they have received for 10.8 years of schooling and aged at 508 months (42 years old) at the interview on average. They also have $\$ 2,275$ real 2000 dollars of other income (income other than earned and welfare

\footnotetext{
${ }^{25}$ I re-weight the sample based on the SIPP panel weights, assuming that each panel has the same significance.
} 
incomes). $34 \%$ of them only have one child. $29 \%$ are black. $55 \%$ live with multiple families (relatives or cohabiting). Finally, $12 \%$ of them have their youngest children older than thirteen years old (but younger than eighteen years old, as required by the sample construction).

\section{$6 \quad$ Estimation Results}

\subsection{Main Results}

The first two columns of Table 7 show the coefficient estimates of the policy effects $(\hat{\beta})$ using the bivariate probit model described in Section $4 .{ }^{26}$ As expected, the estimate for the correlation coefficient $(\hat{\rho})$ between welfare use and work is negative at -.63 .

As have been discussed in Section 3, an underlying assumption for the validity of a difference-in-difference estimator is a parallel trend between the control and the treatment groups. As we see in Table 7, none of the DD estimates on welfare use nor work decisions before 1995 are significant. It implies that there are no significant differences in the pre-expansion trends between families with one child and those with more than one child. These estimates give us some confidence in the identification strategy.

Next, I calculate changes in the marginal probabilities of welfare use and work decisions due to changes in the policy variables using the bivariate probit estimates. The results are shown in the last two columns of Table 7 .

There are several noteworthy points. First, the EITC expansion did not affect single mothers' decisions until 1996. This corresponds to the widening gap in the

\footnotetext{
${ }^{26}$ For the purpose of simple presentation, I do not report the estimates of other explanatory variables which include year- and state-fixed effects, individual characteristics mentioned in Equation A.1, and two excluded variables used in the work latent variable equation.
} 
EITC generosities that began in 1993 between families with one child and those with two or more children. For example, families with two or more children received only $\$ 490$ (or 24\%) more in the maximum EITC credit than their one-child counterparts. The gap increased to $\$ 1,006$ (33\% more) in 1995 , and then further to $\$ 1,404(65 \%$ more) in 1996. The gap is unchanged since 1996, but the credit levels are adjusted according to the price index (see Table 1).

Starting from 1996, the EITC expansion significantly reduced welfare use among low-skilled single mothers by $3.8,7.3,8.4$, and 5.6 percentage points annually in 1996, 1997, 1998, and 1999, respectively, compared to the 1993 level. In 2000, this effect, although still negative (-4.4 percentage points), is not significant. These estimates suggest that the 1993 and subsequent expansion in the EITC program plays an important role in explaining the decrease in welfare use among families with more than one child.

As for the effects of welfare time limits, the estimates exhibit a similar pattern to that of the effects of the EITC expansion, but the effects are limited to the group of single mothers who have the youngest, youngest child. Welfare time limits decrease the likelihood of welfare use for a single mother who has her youngest child no older than five years old by about $2.4 \%$, and increase her likelihood of work by about $5.8 \%$. For single mothers whose youngest child is older, the effects are not significant. The directions of some of the estimates are even reversed. ${ }^{27}$ Finally, the remaining initiatives of the welfare reform, roughly represented by whether a state has enacted a work requirement, do not significantly change welfare use for any of the three sub-age groups.

Table 8 reports the average, rather than annual, effects of the policy changes over the period from 1994 to $2000 .^{28}$ The first two columns list the average effects on the

\footnotetext{
${ }^{27}$ Note the comparison group here is the mothers who have their youngest children aged between thirteen to eighteen years old. The estimates on the second youngest group are fairly insignificant, and are not stable over different specifications. However, time limit seems to have pushed the group of mothers who have children aged between ten and thirteen to speed up their welfare use.

${ }^{28}$ The average EITC effect is estimated by a DD estimator where a 1993 Plus indicator, rather than annual indicators, is used as the first difference. Note that the estimates for welfare time limits and work requirements are not statistically different between annual and average effects
} 
two binary decisions. The expansion explains about 2.6 percentage points decrease in welfare use among this group of low-skilled single mothers after 1993. Data used to draw Figure 1 suggests that in 1993, the welfare participation rate among this group of low-skilled single mothers is at about 30.7\%. By the end of the 1990s, the same rate is at only $11.2 \%$. As a result, the 1993 and consequent expansion in the EITC program explains for about $13 \%\left(=\frac{2.6}{30.7-11.2} \%\right)$ of the decrease in the welfare participation rate. In the mean time, welfare time limits (on the below five years old group) explains for about the same magnitude of the decline in welfare use if the low-skilled single mothers.

The last two columns of Table 8 further distinguishes the effects of policy changes on a mother's likelihood of choosing between the four different welfare/work alternatives. Ideally, we would like welfare participants to be able to support themselves through employment and hence leave welfare. This suggests that one way to evaluate the success of a policy is its effectiveness on increasing the (no welfare, work) alternative. In this perspective, both the EITC expansion and the welfare reform have succeeded. Based on the estimates, both policy changes significantly increase a low-skilled single mother's likelihood of the ideal state, i.e., work and not on welfare, while it almost uniformly decreases the likelihoods of a mother's all other alternatives. $^{29}$

Also, as we see from the table, since policy changes affect the four alternatives very unevenly, investigating the marginal probabilities of either welfare use or work alone masks significant compositional changes. Notably, although the sign is negative, the expansion seems to have a minor effect on those welfare participants who were already working, both in terms of the magnitude and the significance of the estimate. $^{30}$ Combined with the fact that there is a net increase in the marginal estimations, except for the work effect of time limits on single mothers with the youngest, youngest child group.

${ }^{29}$ Note that the definition of work used here is having reported ten hours or more of work a week in the previous month. The higher the condition is, the lower the ratio of people will be qualified as "working".

${ }^{30} \mathrm{By}$ the estimation framework, we are only able to know the net effects of the policy changes on these alternatives. One potential explanation of the ineffectiveness of the EITC expansion on the (welfare, work) alternative is that as the EITC increases the likelihood of work (an increase 
probability of work, it is clear that the main driving force of the increase in the work likelihood due to the EITC is from people who left welfare after the expansion. Further, this disproportional decrease also explains the sharp increase in work among welfare participants in the late 1990s as seen in Figure 1(b). That is, due to the shrink of the group of people who are not working and rely solely on welfare and the relative stable population of those who are simultaneously on welfare and working, the ratio of work among welfare participants increase.

To evaluate the relative effectiveness of policies Table 9 calculates the elasticities of the explanatory variables, evaluated at the sample mean. The elasticity captures the percentage change in the decision variable due to the change in one's status, i.e., change in the applicability of a certain policy. There are some noteworthy points based on the elasticity estimates. First, the (welfare, no work) alternative is the most responsive one to both policy changes. This can be viewed as another support of the success of the EITC and the welfare reform. As both policies are targeting low-income families, which are most susceptible of falling into this category, the responsiveness indicates that these two policies are effectively affecting their target group. Second, we see that the absolute values of the EITC elasticities are all greater than their welfare time-limit counterparts. It implies that single mothers react to the EITC expansion more strongly than the welfare time limits. Judging by the relative responsiveness of the targeted population to different policies, it can be said that the rewarding policy, i.e., the EITC, is more effective in motivating single mothers to leave the undesired status than the punishing policy, i.e., the welfare time limit.

Finally, as age is an important indicator of the life experience of a single mother, it is of interest to see if mothers of different age groups react differently to the policy changes. In particular, it is ideal if policies can move younger mothers from welfare dependence and joblessness to independently supporting themselves. I separate lowskilled single mothers into three groups: born in 1965 and after (and hence below 30 when the policies took place in the mid 1990s), born in between 1956 and 1964, and

in (welfare, work), holding welfare constant), it also reduces that of welfare use (an decrease in (welfare, work), holding work constant). 
born before 1956, then re-estimated the model for the three sub-age groups. The results are shown in Table 10.

The magnitudes of the results indicate that, as mother ages, the EITC expansion plays an increasingly more significant role in increasing the likelihood of work (However, they are not statistically different from each other). In the mean time, EITC has its strongest effect on reducing the welfare use among single mothers who were born in between 1956 and 1965 (hence were mostly in their 30s in the mid 1990s, when both policies took place). In fact, using similarly defined sample of single mothers from NLSY 79 (who were born in the same period of time), I get estimates of comparable magnitudes. On the other hand, for younger mothers who were born after 1965, although the signs are correct, neither policy has significant effects on either their welfare use or work decisions. Based on this result, a further study may be needed to investigate the relative effectiveness of policies on this particular group of people.

\subsection{Identification Check}

One of most important disadvantages of a non-linear probability model is that we can not control the individual fixed-effect by the standard first difference method. Due to this restriction, the bivariate probit model essentially treats SIPP sample as cross-sectional. To see if the unobserved individual characteristics impose a significant restriction, I estimate linear probability models of welfare use and work with individual fixed-effects. The results are reported in Table 11. The detailed specification of the linear probability model is discussed in Appendix A.1

Compared with the linear probability model, the bivariate probit model estimates that the effects of EITC expansion on welfare use and work are fairly stable. In general, the bivariate probit model shows slightly weaker policy effects on welfare use and higher effects on work. This is especially true for the effect of the EITC expansion. Furthermore, linear probability models return more significant results. 
Under the specification, welfare time limits also play a significant role in reducing welfare use (however, also reducing work) among mothers whose youngest child is between five and ten years old. Furthermore, the remaining welfare reform initiatives, roughly represented by whether a state has implemented work requirements, seem to increase the welfare use among low-skilled single mothers under the linear probability framework.

The estimation of the linear probability model is different from the bivariate probit model in that I also include an individual fixed-effect to control for the effects from unobserved individual heterogeneity. In this sense, the comparison between the estimates of the bivariate probit model and the linear probability model is also a check of the seriousness of the potential bias induced by unobserved heterogeneity. The estimates seem to suggest that the unobserved individual characteristics affect the likelihood of having youngest children younger than thirteen years old more than the decision of having one or two or more children. As a result, once we control it by adding the individual fixed-effect, the real welfare reform effects are revealed. ${ }^{31}$

Finally, one of the underlying identifying assumption is that the EITC expansion has the same effect on families with two or more children. In Table 12, I test this assumption by examining whether there are differences between families with two children and those with three or more children. The results indicate that, except for very few years, the DD estimators for the EITC effects are not significant. Generally speaking, these two types of families do not exhibit significant differences in their behaviors. This provides further evidence about the validity of the identification strategy of the EITC expansion effect.

\footnotetext{
${ }^{31}$ One may worry about the significance of the welfare reform coefficients in the linear probability model are due to its distributional assumption. If this is true, a linear probability model without controlling for individual fixed-effect is also likely to have a negative estimate on these coefficients. Based on results not shown here, this is not the case. When individual fixed-effect is not present, the negative effect of the time limit, for example, disappears and turns positive (and also insignificant).
} 


\section{Concluding Remarks}

The 1990s saw a significant focus on mechanisms to reduce welfare caseloads. The overall public policy goal was to reduce welfare and increase work among poor families with dependent children. Among the major public policies aiming at achieving the above purposes, this study focuses on the effects of the expansion in the EITC program in 1993 and welfare time limits.

Previous studies on the subject generally focus on welfare participation and work as two separate decisions, and have not considered them as a joint decision. Assuming people can choose to be on welfare and to work simultaneously, we have four possible alternatives: (work, no welfare), (no work, no welfare), (no work, welfare) and (work, welfare). The purpose of many public programs are essentially trying to move people from the last two groups to the first one. The disadvantage of treating them as separate decisions is that we will not know how policies affect these four welfare/work alternatives.

Using a bivariate probit model of welfare use and work decisions, the estimates indicate that, conditional on welfare reform initiatives, state fixed-effect, business cycle factors, as well as a set of individual characteristics, the EITC expansion explains for about 2.6 percentage points decrease in the welfare use after 1993. In the mean time, welfare time limits explains for about the same magnitude of the decline of welfare caseloads.

Also, the estimates suggest that both policy changes significantly increase a lowskilled single mother's likelihood of the ideal state, i.e., (work, no welfare), while it almost uniformly decreases the likelihoods of a mother's selection of the alternative states. Furthermore, the increase in work among welfare participants is mostly due to the relative ineffectiveness of the policies that are able to reduce the net population of those who are simultaneously on welfare and working.

The elasticity estimates show that the absolute values of the EITC elasticities on four alternatives are all greater than those of welfare time limits elasticities. This 
indicates that single mothers react to the EITC expansion more strongly than the welfare time limits. Among them, those who were not employed and dependent solely on welfare before the expansion were most responsive to the EITC expansion.

There are two related questions for my further investigation. First, it is important to further investigate single mothers who are neither working nor on welfare. This group of mothers comprise a large proportion of my sample. A glance at the data indicates that they are not unlike their counterparts in other groups in terms of financial status. However, a more careful examination is needed to know why and how they remain both jobless and welfare-less. A second and more sophisticated question is whether the EITC expansion or welfare reform affect a single mothers' occupational choices. An understanding of the factors that affect single mothers occupation choices is important as such information could be used to design more effective job-training programs. A first glance at the data indicates that single mothers who were working before the EITC expansion "move up" to jobs that require more skills than the jobs obtained by their counterparts who were not working. This may suggest that (i), their work experience is able to help them find better jobs; or (ii), financial incentives might motivate them to search harder for a better job. 


\section{References}

Blank, R. and Ruggles, P., 1996, "When Do Women Use Aid to Families with Dependent Children and Food Stamps? The Dynamics of Eligibility versus Participation." Journal of Human Resources, Winter, 31 (1), 57-89.

Congressional Research Service (CRS), 2005, "TANF Cash Benefits as of January 1, 2004," September, CRS Report for Congress, The Library of Congress, Washington, D.C.

Council of Economic Advisors (CEA), 1997, "Explaining the Decline in Welfare Receipt, 1993-1993." Washington, D.C.

—, 1999, "The Effects of Welfare Policy and the Economic Expansion on Welfare Caseloads: An Update," Washing, D.C.

Greene W., 2001, "Fixed and Random Effects in Nonlinear Models," January, manuscript, Department of Economics, Stern School of Business, New York University.

Grogger, J., and Michalopoulos, C., 2003, "Welfare Dynamics under Time Limits." Journal of Political Economics, 111 (3), 530-554.

Grogger, J., 2003, "The Effects of Time Limits, the EITC, and Other Policy Changes on Welfare Use, Work, and Income Among Female-Headed Families." Review of Economics and Statistics, May, 85(2), 394-408.

Grogger, J., 2004, "Time Limits and Welfare Use." Journal of Human Resources, Spring, 39 (2), 405-424.

Hotz, V., Mullin, Charles H., and Scholz, John Karl, 2005, "Examining the Effect of the Earned Income Tax Credit on the Labor Market Participation of Families on Welfare." Draft, December, http://www.ssc.wisc.edu/ scholz/Research/EITC_Draft.pdf.

Hotz, V. and Scholz, John Karl, 2003, "The Earned Income Tax," Means-Tested Transfer Programs in the United States, edited by Saks E., and Moffitt, R. (edited), University of Chicago Press, October.

Keane M. and Wolpin K., 2006, "The Role of Labor and Marriage Markets, Preference Heterogeneity and the Welfare System in the Life Cycle Decisions of Black, Hispanic and White Women," PIER Working Paper 06-004, Penn Institute for Economic Research, Department of Economics, University of Pennsylvania.

Meyer, Bruce, and Rosenbaum, Dan, 2001 "Welfare, the Earned Income Tax Credit, and the Labor Supply of Single Mothers." Quarterly Journal of Economics, August, CXVI(3), 1063-1114.

Ochel, Wolfgang, 2004, "Welfare Time Limits in the United States - Experience with A New Welfare-to-Work Approach." June, CESIFO Working Paper No. 1210, CESIFO, Munich, Germany.

Terra, M., Sanders, S., and Smith., J., "Estimates of Effective Guarantees and Tax Rates in the AFDC Program for the POST-OBRA Period." Journal of Human 
Resources, Vol. 34(2), Spring, 1999, 12 C345. 


\section{Tables and Graphs}

Table 1: Earned Income Tax Credit Parameters, 1979-2001

\begin{tabular}{|c|c|c|c|c|c|}
\hline Year & $\begin{array}{l}\text { Phase-in } \\
\text { Rate (\%) }\end{array}$ & $\begin{array}{c}\text { Phase-in } \\
\text { Range }\end{array}$ & $\begin{array}{l}\text { Max } \\
\text { Credit }\end{array}$ & $\begin{array}{l}\text { Phase-out } \\
\text { Rate }(\%)\end{array}$ & $\begin{array}{c}\text { Phase-out } \\
\text { Range }\end{array}$ \\
\hline $1975-78$ & 10 & $\$ 0-\$ 4,000$ & $\$ 400$ & 10 & $\$ 4,000-\$ 8,000$ \\
\hline $1979-84$ & 10 & $0-5,000$ & 500 & 12.5 & $6,000-10,000$ \\
\hline $1985-86$ & 11 & $0-5,000$ & 550 & 12.22 & $6,500-11,000$ \\
\hline 1987 & 14 & $0-6,080$ & 851 & 10 & $6,920-15,432$ \\
\hline 1988 & 14 & $0-6,240$ & 874 & 10 & $9,840-18,576$ \\
\hline 1989 & 14 & $0-6,500$ & 910 & 10 & $10,240-19,340$ \\
\hline 1990 & 14 & $0-6,810$ & 953 & 10 & $10,730-20,264$ \\
\hline $1991^{a}$ & $\begin{array}{l}16.71^{1} \\
17.32^{2}\end{array}$ & $0-7,140$ & $\begin{array}{l}1,192 \\
1,235\end{array}$ & $\begin{array}{l}11.93 \\
12.36\end{array}$ & $\begin{array}{c}11,250-21,250 \\
11,250-21,250\end{array}$ \\
\hline $1992^{a}$ & $\begin{array}{l}17.61^{1} \\
18.42^{2}\end{array}$ & $0-7,520$ & $\begin{array}{l}1,324 \\
1,384\end{array}$ & $\begin{array}{l}12.57 \\
13.14\end{array}$ & $\begin{array}{c}11,840-22,370 \\
11,840-22,370\end{array}$ \\
\hline $1993^{a}$ & $\begin{array}{l}18.51^{1} \\
19.52^{2}\end{array}$ & $0-7,750$ & $\begin{array}{l}1,434 \\
1,511\end{array}$ & $\begin{array}{l}13.21 \\
13.93\end{array}$ & $\begin{array}{c}12,200-23,050 \\
12,200-23,050\end{array}$ \\
\hline 1994 & $\begin{array}{l}23.61^{1} \\
30.02^{2} \\
7.653^{3}\end{array}$ & $\begin{array}{l}0-7,750 \\
0-8,245 \\
0-4,000\end{array}$ & $\begin{array}{c}2,038 \\
2,528 \\
306\end{array}$ & $\begin{array}{c}15.98 \\
17.68 \\
7.65\end{array}$ & $\begin{array}{c}11,000-23,755 \\
11,000-25,296 \\
5,000-9,000\end{array}$ \\
\hline 1995 & $\begin{array}{l}34.01^{1} \\
36.02^{2} \\
7.653^{3}\end{array}$ & $\begin{array}{l}0-6,160 \\
0-8,640 \\
0-4,100\end{array}$ & $\begin{array}{c}2,094 \\
3,110 \\
314\end{array}$ & $\begin{array}{c}15.98 \\
20.22 \\
7.65\end{array}$ & $\begin{array}{c}11,290-24,396 \\
11,290-26,673 \\
5,130-9,230\end{array}$ \\
\hline 1996 & $\begin{array}{l}34.01^{1} \\
40.02^{2} \\
7.653^{3}\end{array}$ & $\begin{array}{l}0-6,330 \\
0-8,890 \\
0-4,220\end{array}$ & $\begin{array}{c}2,152 \\
3,556 \\
323\end{array}$ & $\begin{array}{c}15.98 \\
21.06 \\
7.65\end{array}$ & $\begin{array}{c}11,610-25,078 \\
11,610-28,495 \\
5,280-9,500\end{array}$ \\
\hline 1997 & $\begin{array}{l}34.01^{1} \\
40.02^{2} \\
7.653^{3}\end{array}$ & $\begin{array}{l}0-6,500 \\
0-9,140 \\
0-4,340\end{array}$ & $\begin{array}{c}2,210 \\
3,656 \\
332\end{array}$ & $\begin{array}{c}15.98 \\
21.06 \\
7.65\end{array}$ & $\begin{array}{r}11,930-25,750 \\
11,930-29,290 \\
5,430-9,770\end{array}$ \\
\hline 1998 & $\begin{array}{l}34.01^{1} \\
40.02^{2} \\
7.653^{3}\end{array}$ & $\begin{array}{l}0-6,680 \\
0-9,390 \\
0-4,460\end{array}$ & $\begin{array}{c}2,271 \\
3,756 \\
341\end{array}$ & $\begin{array}{c}15.98 \\
21.06 \\
7.65\end{array}$ & $\begin{array}{c}12,260-26,473 \\
12,260-30,095 \\
5,570-10,030\end{array}$ \\
\hline 1999 & $\begin{array}{l}34.01^{1} \\
40.02^{2} \\
7.653^{3}\end{array}$ & $\begin{array}{l}0-6,800 \\
0-9,540 \\
0-4,530\end{array}$ & $\begin{array}{c}2,312 \\
3,816 \\
347\end{array}$ & $\begin{array}{c}15.98 \\
21.06 \\
7.65\end{array}$ & $\begin{array}{c}12,460-26,928 \\
12,460-30,580 \\
5,670-10,200\end{array}$ \\
\hline 2000 & $\begin{array}{l}34.01^{1} \\
40.02^{2} \\
7.653^{3}\end{array}$ & $\begin{array}{l}0-6,920 \\
0-9,720 \\
0-4,610\end{array}$ & $\begin{array}{c}2,353 \\
3,888 \\
353\end{array}$ & $\begin{array}{c}15.98 \\
21.06 \\
7.65\end{array}$ & $\begin{array}{c}12,690-27,413 \\
12,690-31,152 \\
5,770-10,380\end{array}$ \\
\hline
\end{tabular}

Source: Hotz and Scholz (2003), Table 1. All are in nominal dollars.

${ }^{a}$ Basic credit only. Does not include supplemental young child or health insurance credits. ${ }^{1}$ Taxpayers with one qualifying child. ${ }^{2}$ Taxpayers with more than one qualifying child. ${ }^{3}$ Childless taxpayers. 


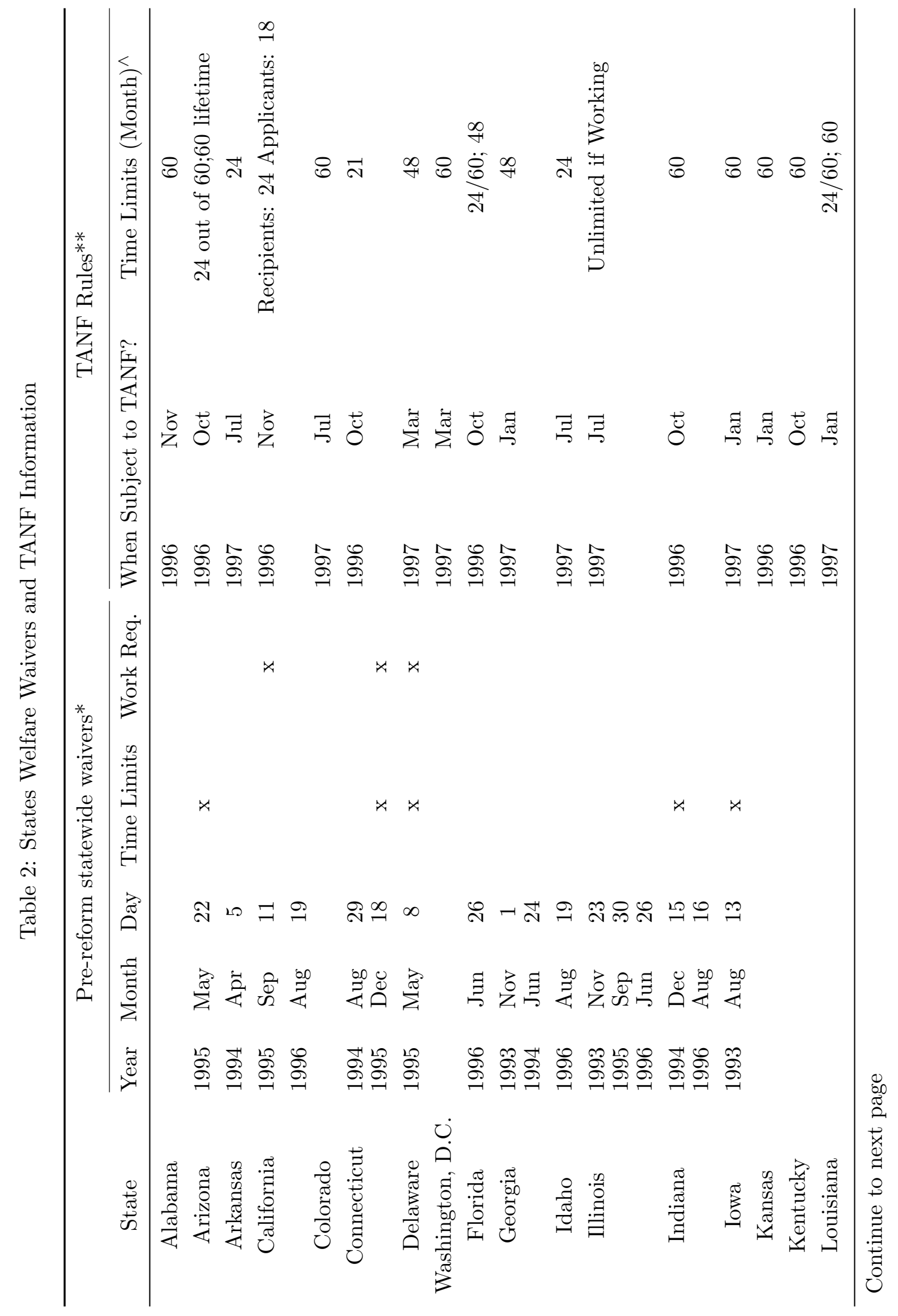




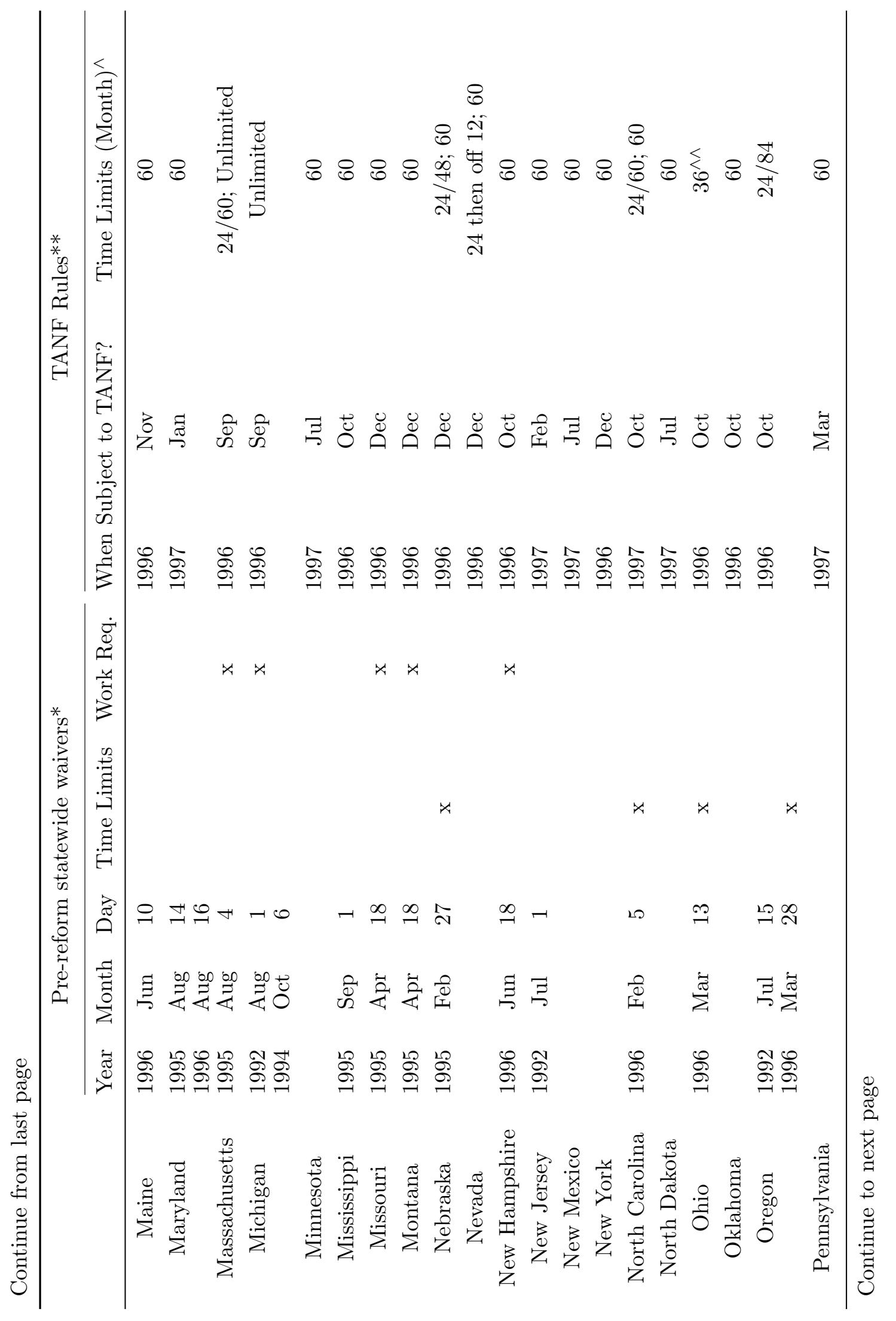




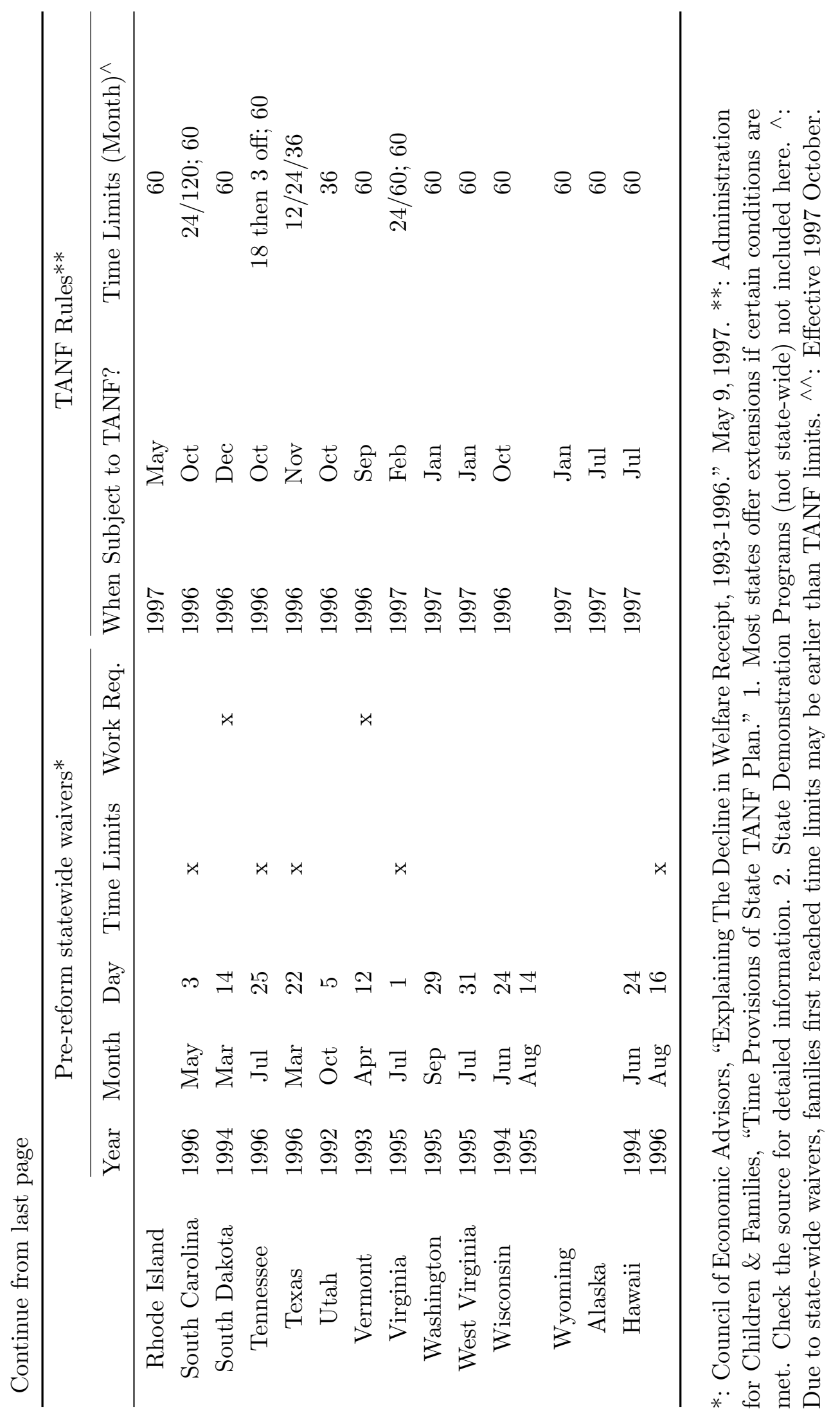




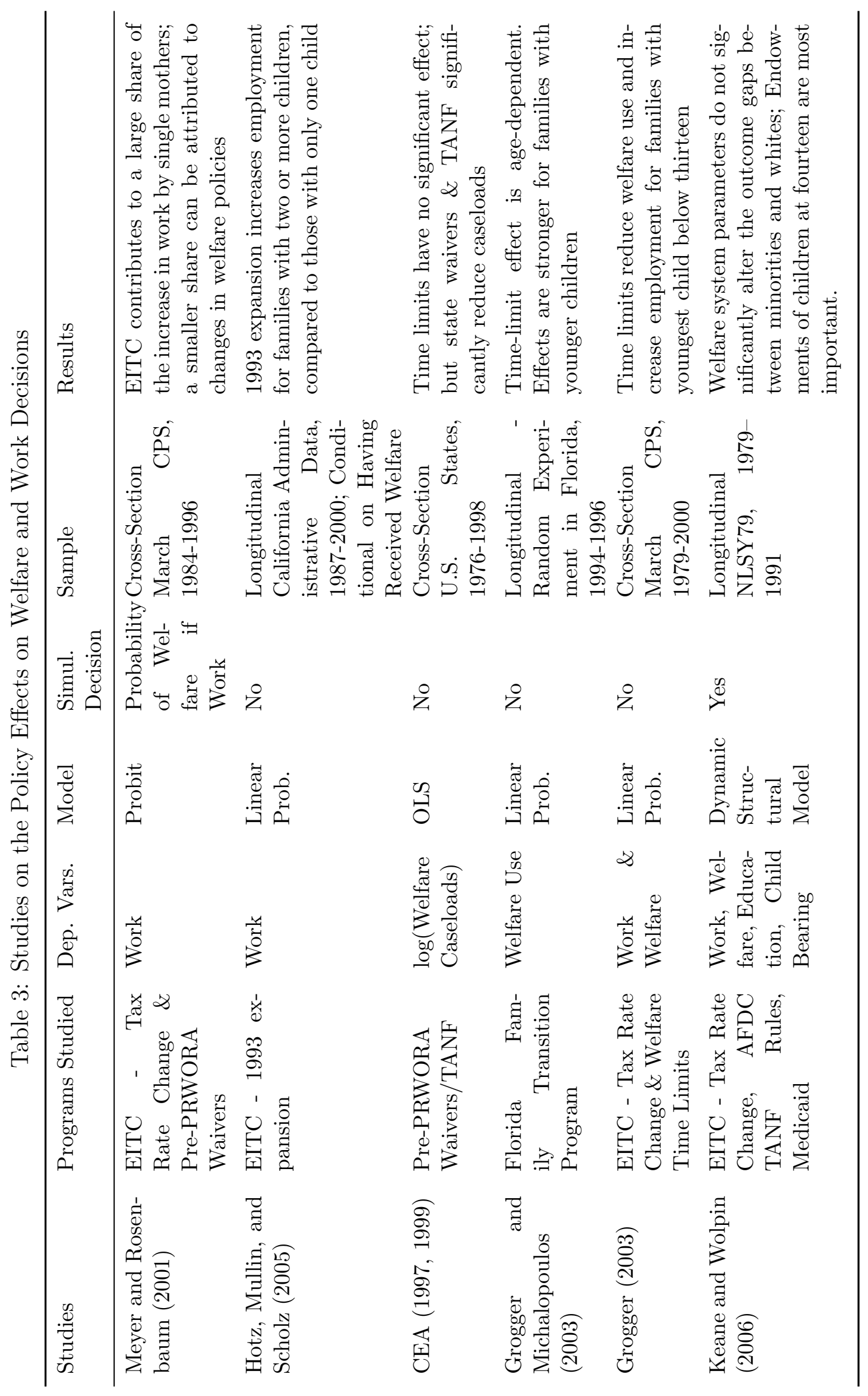


Table 4: Multicollinearity Between Real Maximum Credit and Other Explanatory Variables

\begin{tabular}{|c|c|c|c|}
\hline \multicolumn{4}{|l|}{ Variables } \\
\hline 1979 & $\begin{array}{c}-1522.78^{* * *} \\
(38.795)\end{array}$ & 1990 & $\begin{array}{c}-1391.71^{* * *} \\
(38.911)\end{array}$ \\
\hline 1980 & $\begin{array}{c}-1624.31^{* * *} \\
(38.762)\end{array}$ & 1991 & $\begin{array}{c}-1131.21^{* * *} \\
(38.984)\end{array}$ \\
\hline 1981 & $\begin{array}{c}-1701.24^{* * *} \\
(38.743)\end{array}$ & 1992 & $\begin{array}{c}-1016.08^{* * * *} \\
(39.068)\end{array}$ \\
\hline 1982 & $\begin{array}{c}-1747.50^{* * *} \\
(38.740)\end{array}$ & 1993 & $\begin{array}{c}-920.61^{* * *} \\
(39.227)\end{array}$ \\
\hline 1983 & $\begin{array}{c}-1780.67^{* * *} \\
(38.733)\end{array}$ & 1994 & $\begin{array}{c}-190.94^{* * *} \\
(39.384)\end{array}$ \\
\hline 1984 & $\begin{array}{c}-1808.83^{* * *} \\
(38.739)\end{array}$ & 1995 & $\begin{array}{c}-133.80^{* * *} \\
(39.596)\end{array}$ \\
\hline 1985 & $\begin{array}{c}-1757.60^{* * *} \\
(38.743)\end{array}$ & 1996 & $\begin{array}{c}-106.47^{* * *} \\
(39.849)\end{array}$ \\
\hline 1986 & $\begin{array}{c}-1776.59^{* * *} \\
(38.775)\end{array}$ & 1997 & $\begin{array}{r}-77.70^{* *} \\
(40.378)\end{array}$ \\
\hline 1987 & $\begin{array}{c}-1378.39^{* * *} \\
(38.797)\end{array}$ & 1998 & $\begin{array}{c}-8.67 \\
(41.293)\end{array}$ \\
\hline 1988 & $\begin{array}{c}-1392.38^{* * * *} \\
(38.817)\end{array}$ & 1999 & $\begin{array}{c}-68.65 \\
(43.997)\end{array}$ \\
\hline 1989 & $\begin{array}{c}-1394.31^{* * *} \\
(38.848)\end{array}$ & $\begin{array}{l}\text { Number of } \\
\text { Children }\end{array}$ & $\begin{array}{c}11.93^{* * *} \\
(1.162)\end{array}$ \\
\hline Constant & $\begin{array}{c}2558.65^{* * *} \\
(38.546)\end{array}$ & $\begin{array}{l}\text { Age of Youngest } \\
\text { Child }\end{array}$ & $\begin{array}{l}-.042 \\
(.408)\end{array}$ \\
\hline$R^{2}$ & .946 & & \\
\hline $\bar{R}^{2}$ & .946 & & \\
\hline Observations & 7,949 & & \\
\hline
\end{tabular}

1. ***, **, *: represent significance at $1 \%, 5 \%$ and $10 \%$ confidence levels, respectively. 
Table 5: Multicollinearity Between (Real Maximum Credit $\times$ Age of the Youngest Child) and Other Explanatory Variables

\begin{tabular}{|c|c|c|c|}
\hline Variables & & & \\
\hline 1979 & $\begin{array}{c}102.10 \\
(110.086)\end{array}$ & 1990 & $\begin{array}{c}-60.01 \\
(123.869)\end{array}$ \\
\hline 1980 & $\begin{array}{c}-56.77 \\
(107.236)\end{array}$ & 1991 & $\begin{array}{c}873.41^{* * *} \\
(130.231)\end{array}$ \\
\hline 1981 & $\begin{array}{l}-197.53^{*} \\
(105.918)\end{array}$ & 1992 & $\begin{array}{c}1365.30^{* * *} \\
(137.122)\end{array}$ \\
\hline 1982 & $\begin{array}{c}-406.91^{* * *} \\
(105.636)\end{array}$ & 1993 & $\begin{array}{c}1749.82^{* * *} \\
(148.693)\end{array}$ \\
\hline 1983 & $\begin{array}{c}-567.05^{* * *} \\
(105.405)\end{array}$ & 1994 & $\begin{array}{c}4959.24^{* * *} \\
(159.773)\end{array}$ \\
\hline 1984 & $\begin{array}{c}-808.57^{* * *} \\
(106.389)\end{array}$ & 1995 & $\begin{array}{c}5354.07^{* * *} \\
(173.241)\end{array}$ \\
\hline 1985 & $\begin{array}{c}-793.47^{* * *} \\
(107.249)\end{array}$ & 1996 & $\begin{array}{c}5390.57^{* * *} \\
(187.923)\end{array}$ \\
\hline 1986 & $\begin{array}{c}-1059.54^{* * *} \\
(110.717)\end{array}$ & 1997 & $\begin{array}{c}5731.23^{* * *} \\
(215.778)\end{array}$ \\
\hline 1987 & $\begin{array}{c}9.96 \\
(113.201)\end{array}$ & 1998 & $\begin{array}{c}4619.79^{* * *} \\
(257.442)\end{array}$ \\
\hline 1988 & $\begin{array}{c}-62.92 \\
(115.293)\end{array}$ & 1999 & $\begin{array}{c}1430.69^{* * *} \\
(356.694)\end{array}$ \\
\hline 1989 & $\begin{array}{c}-29.34 \\
(118.092)\end{array}$ & $\begin{array}{l}\text { Number of } \\
\text { Children }\end{array}$ & $\begin{array}{c}170.02^{* * *} \\
(18.343)\end{array}$ \\
\hline $\begin{array}{l}\text { Constant } \\
\text { Term }\end{array}$ & $\begin{array}{c}-842.06^{* * *} \\
(93.888)\end{array}$ & $\begin{array}{l}\text { Age Youngest } \\
\text { Child }\end{array}$ & $\begin{array}{c}1371.73^{* * *} \\
\quad(6.810)\end{array}$ \\
\hline$R^{2}$ & .876 & & \\
\hline $\bar{R}^{2}$ & .876 & & \\
\hline Observations & 7,949 & & \\
\hline
\end{tabular}

1. $* * *, * *, *$ : represent significance at $1 \%, 5 \%$ and $10 \%$ confidence levels, respectively. 
Table 6: Weighted Summary Statistics of Relevant Variables

\begin{tabular}{|c|c|c|c|}
\hline Variables & Sample Mean & Variables & Sample Mean \\
\hline Dependent Variables & & $($ Time Limit $) \times$ & \\
\hline $\begin{array}{l}\overline{\text { AFDC/TANF }} \\
\text { Participation }\end{array}$ & $\begin{array}{l}.16 \\
(.37)\end{array}$ & $<5$ Years Old & $\begin{array}{l}.23 \\
(.42)\end{array}$ \\
\hline \multirow[t]{2}{*}{ Work $^{\dagger}$} & $\begin{array}{l}.51 \\
(.50)\end{array}$ & $>5,<=10$ & $\begin{array}{l}.08 \\
(.27)\end{array}$ \\
\hline & & $>10,<=13$ & $\begin{array}{l}.02 \\
(.15)\end{array}$ \\
\hline \multicolumn{4}{|c|}{ Effects of Policy Changes } \\
\hline \multicolumn{2}{|l|}{$\overline{(\text { Two or More Kids }) \times}$} & \multicolumn{2}{|c|}{ Individual Characteristics } \\
\hline 1989 & $\begin{array}{l}.56 \\
(.50)\end{array}$ & Education & $\begin{array}{l}10.78 \\
(2.20)\end{array}$ \\
\hline 1990 & $\begin{array}{l}.55 \\
(.50)\end{array}$ & $\begin{array}{l}\text { Age of } \\
\text { Mother }\end{array}$ & $\begin{array}{c}508.2 \\
(197.27)\end{array}$ \\
\hline 1991 & $\begin{array}{l}.57 \\
(.49)\end{array}$ & $\begin{array}{l}\text { Other } \\
\text { Income }\end{array}$ & $\begin{array}{c}2275.20 \\
(7361.75)\end{array}$ \\
\hline 1992 & $\begin{array}{l}.58 \\
(.49)\end{array}$ & Have 2 Kids & $\begin{array}{c}.22 \\
(.42)\end{array}$ \\
\hline 1994 & $\begin{array}{l}.60 \\
(.49)\end{array}$ & Have 3 Kids & $\begin{array}{l}.13 \\
(.34)\end{array}$ \\
\hline 1995 & $\begin{array}{l}.59 \\
(.49)\end{array}$ & $4+$ Kids & $\begin{array}{l}.31 \\
(.46)\end{array}$ \\
\hline 1996 & $\begin{array}{l}.71 \\
(.45)\end{array}$ & Black & $\begin{array}{l}.29 \\
(.45)\end{array}$ \\
\hline 1997 & $\begin{array}{l}.82 \\
(.38)\end{array}$ & Multi-Families & $\begin{array}{l}.55 \\
(.50)\end{array}$ \\
\hline 1998 & $\begin{array}{l}.82 \\
(.38)\end{array}$ & $<5$ Years Old & $\begin{array}{l}.54 \\
(.50)\end{array}$ \\
\hline 1999 & $\begin{array}{l}.82 \\
(.39)\end{array}$ & $>5,<=10$ & $\begin{array}{l}.24 \\
(.42)\end{array}$ \\
\hline 2000 & $\begin{array}{l}.80 \\
(.40)\end{array}$ & $>10,<=13$ & $\begin{array}{l}.10 \\
(.30)\end{array}$ \\
\hline Work Requirement & $\begin{array}{l}.33 \\
(.47)\end{array}$ & & \\
\hline $\begin{array}{l}\text { Observations } \\
\text { Mother-Years }\end{array}$ & 145,291 & & \\
\hline
\end{tabular}

$\dagger$ Work is defined as having worked for more than 10 hours a week in previous month.

$\ddagger$ All monetary terms are in real 2000 dollars deflated by PCE deflator. 
Table 7: Estimation Results - Assuming Bivariate Normal Distribution

\begin{tabular}{|c|c|c|c|c|}
\hline & \multicolumn{2}{|c|}{ Coefficient Estimates } & \multicolumn{2}{|c|}{ Marginal Effects } \\
\hline & Welfare Use & Work $^{\dagger}$ & Welfare Use & Work $^{\dagger}$ \\
\hline \multicolumn{5}{|c|}{ (Two or More Kids) $\times$} \\
\hline 1989 & $\begin{array}{l}.117 \\
(.148)\end{array}$ & $\begin{array}{l}.205 \\
(.128)\end{array}$ & $\begin{array}{l}.026 \\
(.035)\end{array}$ & $\begin{array}{l}.082 \\
(.051)\end{array}$ \\
\hline 1990 & $\begin{array}{l}.029 \\
(.109)\end{array}$ & $\begin{array}{l}.102 \\
(.094)\end{array}$ & $\begin{array}{l}.006 \\
(.023)\end{array}$ & $\begin{array}{l}.041 \\
(.037)\end{array}$ \\
\hline 1991 & $\begin{array}{l}.027 \\
(.091)\end{array}$ & $\begin{array}{l}-.011 \\
(.079)\end{array}$ & $\begin{array}{l}.006 \\
(.020)\end{array}$ & $\begin{array}{l}-.004 \\
(.031)\end{array}$ \\
\hline 1992 & $\begin{array}{l}-.091 \\
(.065)\end{array}$ & $\begin{array}{l}.051 \\
(.056)\end{array}$ & $\begin{array}{l}-.018 \\
(.012)\end{array}$ & $\begin{array}{l}.021 \\
(.022)\end{array}$ \\
\hline 1994 & $\begin{array}{l}.066 \\
(.073)\end{array}$ & $\begin{array}{l}-.021 \\
(.061)\end{array}$ & $\begin{array}{l}.014 \\
(.016)\end{array}$ & $\begin{array}{l}-.008 \\
(.024)\end{array}$ \\
\hline 1995 & $\begin{array}{l}-.014 \\
(.116)\end{array}$ & $\begin{array}{l}.131 \\
(.095)\end{array}$ & $\begin{array}{l}-.003 \\
(.024)\end{array}$ & $\begin{array}{l}.052 \\
.038)\end{array}$ \\
\hline 1996 & $\begin{array}{c}-.198^{* *} \\
(.095)\end{array}$ & $\begin{array}{c}.336^{* * *} \\
(.080)\end{array}$ & $\begin{array}{c}-.038^{* *} \\
(.017)\end{array}$ & $\begin{array}{c}.133^{* * *} \\
.031)\end{array}$ \\
\hline 1997 & $\begin{array}{c}-.429^{* * *} \\
(.109)\end{array}$ & $\begin{array}{l}.361^{* * * *} \\
(.091)\end{array}$ & $\begin{array}{c}-.073^{* * *} \\
(.014)\end{array}$ & $\begin{array}{c}.143 * * * \\
(.035)\end{array}$ \\
\hline 1998 & $\begin{array}{c}-.521^{* * *} \\
(.114)\end{array}$ & $\begin{array}{c}.241^{* * *} \\
(.095)\end{array}$ & $\begin{array}{c}-.084^{* * *} \\
(.013)\end{array}$ & $\begin{array}{c}.096^{* * *} \\
(.037)\end{array}$ \\
\hline 1999 & $\begin{array}{c}-.312^{* *} \\
(.129)\end{array}$ & $\begin{array}{l}.211^{* *} \\
(.097)\end{array}$ & $\begin{array}{c}-.056^{* * *} \\
(.019)\end{array}$ & $\begin{array}{l}.084^{* *} \\
(.039)\end{array}$ \\
\hline 2000 & $\begin{array}{l}-.190 \\
(.489)\end{array}$ & $\begin{array}{l}.475 * * \\
(.213)\end{array}$ & $\begin{array}{l}-.044 \\
(.125)\end{array}$ & $\begin{array}{l}.185^{* *} \\
(.078)\end{array}$ \\
\hline \multicolumn{5}{|l|}{$($ Time Limit $) \times$} \\
\hline$<5$ Years Old & $\begin{array}{c}-.122^{* *} \\
(.053)\end{array}$ & $\begin{array}{c}.145^{* * *} \\
(.049)\end{array}$ & $\begin{array}{c}-.024^{* *} \\
(.010)\end{array}$ & $\begin{array}{c}.058^{* * *} \\
(.020)\end{array}$ \\
\hline$>5,<=10$ & $\begin{array}{l}.013 \\
(.091)\end{array}$ & $\begin{array}{l}-.064 \\
(.082)\end{array}$ & $\begin{array}{l}.003 \\
(.019)\end{array}$ & $\begin{array}{l}-.025 \\
(.033)\end{array}$ \\
\hline$>10,<=13$ & $\begin{array}{l}.290^{* *} \\
(.142)\end{array}$ & $\begin{array}{l}.093 \\
(.122)\end{array}$ & $\begin{array}{l}.070^{*} \\
(.039)\end{array}$ & $\begin{array}{l}.037 \\
(.049)\end{array}$ \\
\hline \multicolumn{5}{|c|}{ (Work Requirement) $\times$} \\
\hline$<5$ Years Old & $\begin{array}{l}.005 \\
(.054)\end{array}$ & $\begin{array}{l}-.013 \\
(.049)\end{array}$ & $\begin{array}{l}.001 \\
(.011)\end{array}$ & $\begin{array}{l}-.005 \\
(.019)\end{array}$ \\
\hline$>5,<=10$ & $\begin{array}{l}.096 \\
(.089)\end{array}$ & $\begin{array}{l}.071 \\
(.082)\end{array}$ & $\begin{array}{l}.021 \\
(.020)\end{array}$ & $\begin{array}{l}.028 \\
.033)\end{array}$ \\
\hline$>10,<=13$ & $\begin{array}{l}-.089 \\
(.144)\end{array}$ & $\begin{array}{c}-.288^{* *} \\
(.125)\end{array}$ & $\begin{array}{l}-.018 \\
(.027)\end{array}$ & $\begin{array}{c}-.112^{* *} \\
(.047)\end{array}$ \\
\hline
\end{tabular}

$[\dagger]$ Work is defined as having worked for more than 10 hours a week in previous month. $* * *, * *, *$ : represent significance at $1 \%, 5 \%$ and $10 \%$ confidence levels, respectively. 
Table 8: Marginal Effects on Probabilities Due to Policy Changes

\begin{tabular}{|c|c|c|c|c|c|c|}
\hline & \multicolumn{2}{|c|}{ Binary Decisions } & \multicolumn{4}{|c|}{ Four Alternatives } \\
\hline & Welfare & Work & $\begin{array}{c}\text { No Welfare } \\
\text { No Work }\end{array}$ & $\begin{array}{c}\text { No Welfare } \\
\text { Work }\end{array}$ & $\begin{array}{c}\text { Welfare } \\
\text { No Work }\end{array}$ & $\begin{array}{c}\text { Welfare } \\
\text { Work }\end{array}$ \\
\hline $\begin{array}{l}(\text { Two or More Kids }) \times \\
(\text { Year }>1993)\end{array}$ & $\begin{array}{c}-.026^{* *} \\
(.013)\end{array}$ & $\begin{array}{c}.053^{* * *} \\
(.022)\end{array}$ & $\begin{array}{l}-.028 \\
(.019)\end{array}$ & $\begin{array}{c}.054^{* * *} \\
(.021)\end{array}$ & $\begin{array}{c}-.025^{* *} \\
(.012)\end{array}$ & $\begin{array}{l}-.001 \\
(.002)\end{array}$ \\
\hline $\begin{array}{l}(\text { Time Limit }) \times \\
<5 \text { Years Old }\end{array}$ & $\begin{array}{c}-.026^{* * *} \\
(.010)\end{array}$ & $\begin{array}{c}.070^{* * *} \\
(.020)\end{array}$ & $\begin{array}{c}-.045^{* * *} \\
(.017)\end{array}$ & $\begin{array}{c}.070^{* * *} \\
(.019)\end{array}$ & $\begin{array}{c}-.026^{* * *} \\
(.009)\end{array}$ & $\begin{array}{l}.0001 \\
(.002)\end{array}$ \\
\hline$>5,<=10$ & $\begin{array}{l}-.007 \\
(.019)\end{array}$ & $\begin{array}{l}-.020 \\
(.034)\end{array}$ & $\begin{array}{l}.025 \\
(.030)\end{array}$ & $\begin{array}{l}-.018 \\
(.033)\end{array}$ & $\begin{array}{l}-.005 \\
(.017)\end{array}$ & $\begin{array}{l}-.002 \\
(.003)\end{array}$ \\
\hline$>10,<=13$ & $\begin{array}{l}.056 \\
(.036)\end{array}$ & $\begin{array}{l}.036 \\
(.049)\end{array}$ & $\begin{array}{r}-.077^{*} \\
(.044)\end{array}$ & $\begin{array}{l}.021 \\
(.047)\end{array}$ & $\begin{array}{l}.041 \\
(.029)\end{array}$ & $\begin{array}{l}.015 \\
(.009)\end{array}$ \\
\hline $\begin{array}{l}(\text { Work Requirement }) \times \\
<5 \text { Years Old }\end{array}$ & $\begin{array}{l}-.004 \\
(.011)\end{array}$ & $\begin{array}{l}.011 \\
(.019)\end{array}$ & $\begin{array}{l}-.007 \\
(.017)\end{array}$ & $\begin{array}{l}.011 \\
(.019)\end{array}$ & $\begin{array}{l}-.004 \\
(.010)\end{array}$ & $\begin{array}{l}.00002 \\
(.002)\end{array}$ \\
\hline$>5,<=10$ & $\begin{array}{l}.030 \\
(.021)\end{array}$ & $\begin{array}{l}.044 \\
(.034)\end{array}$ & $\begin{array}{c}-.065^{* *} \\
(.029)\end{array}$ & $\begin{array}{l}.035 \\
(.032)\end{array}$ & $\begin{array}{l}.021 \\
(.018)\end{array}$ & $\begin{array}{l}.009^{* *} \\
(.005)\end{array}$ \\
\hline$>10,<=13$ & $\begin{array}{l}.010 \\
(.030)\end{array}$ & $\begin{array}{l}-.095^{*} \\
(.050)\end{array}$ & $\begin{array}{l}.080^{*} \\
(.047)\end{array}$ & $\begin{array}{l}-.091^{*} \\
(.049)\end{array}$ & $\begin{array}{l}.014 \\
(.028)\end{array}$ & $\begin{array}{l}-.004 \\
(.003)\end{array}$ \\
\hline$\rho$ & $\begin{array}{c}-.630^{* * *} \\
(.014)\end{array}$ & & & & & \\
\hline
\end{tabular}

$* * *, * *, *$ : represent significance at $1 \%, 5 \%$ and $10 \%$ confidence levels, respectively. 
Table 9: Elasticities Estimates

\begin{tabular}{|c|c|c|c|c|c|c|}
\hline & \multicolumn{2}{|c|}{ Binary Decisions } & \multicolumn{4}{|c|}{ Four Alternatives } \\
\hline & Welfare & Work & $\begin{array}{l}\text { No Welfare } \\
\text { No Work }\end{array}$ & $\begin{array}{l}\text { No Welfare } \\
\text { Work }\end{array}$ & $\begin{array}{l}\text { Welfare } \\
\text { No Work }\end{array}$ & $\begin{array}{l}\text { Welfare } \\
\text { Work }\end{array}$ \\
\hline $\begin{array}{l}(\text { Two or More Kids }) \times \\
(\text { Year }>1993)\end{array}$ & $\begin{array}{c}-.096^{* *} \\
(.050)\end{array}$ & $\begin{array}{c}.047^{* * * *} \\
(.019)\end{array}$ & $\begin{array}{l}-.034 \\
(.022)\end{array}$ & $\begin{array}{c}.049^{* * *} \\
(.019)\end{array}$ & $\begin{array}{c}-.103^{* *} \\
(.048)\end{array}$ & $\begin{array}{l}-.034 \\
(.083)\end{array}$ \\
\hline $\begin{array}{l}(\text { Time Limit }) \times \\
<5 \text { Years Old }\end{array}$ & $\begin{array}{c}-.050^{* * *} \\
(.020)\end{array}$ & $\begin{array}{c}.031^{* * *} \\
(.009)\end{array}$ & $\begin{array}{c}-.026^{* * *} \\
(.010)\end{array}$ & $\begin{array}{c}.032^{* * *} \\
(.009)\end{array}$ & $\begin{array}{c}-.055^{* * *} \\
(.020)\end{array}$ & $\begin{array}{l}.003 \\
(.036)\end{array}$ \\
\hline$>5,<=10$ & $\begin{array}{l}-.005 \\
(.013)\end{array}$ & $\begin{array}{l}-.003 \\
(.005)\end{array}$ & $\begin{array}{l}.005 \\
(.006)\end{array}$ & $\begin{array}{l}-.003 \\
(.005)\end{array}$ & $\begin{array}{l}-.003 \\
(.012)\end{array}$ & $\begin{array}{l}-.018 \\
(.022)\end{array}$ \\
\hline$>10,<=13$ & $\begin{array}{l}.010^{*} \\
(.006)\end{array}$ & $\begin{array}{l}.002 \\
(.002)\end{array}$ & $\begin{array}{r}-.005^{*} \\
(.003)\end{array}$ & $\begin{array}{l}.001 \\
(.002)\end{array}$ & $\begin{array}{l}.009 \\
(.005)\end{array}$ & $\begin{array}{l}.023^{* *} \\
(.010)\end{array}$ \\
\hline $\begin{array}{l}(\text { Work Requirement }) \times \\
<5 \text { Years Old }\end{array}$ & $\begin{array}{l}-.007 \\
(.019)\end{array}$ & $\begin{array}{l}.004 \\
(.008)\end{array}$ & $\begin{array}{l}-.004 \\
(.009)\end{array}$ & $\begin{array}{l}.005 \\
(.008)\end{array}$ & $\begin{array}{l}-.008 \\
(.018)\end{array}$ & $\begin{array}{l}.0003 \\
(.032)\end{array}$ \\
\hline$>5,<=10$ & $\begin{array}{l}.017 \\
(.011)\end{array}$ & $\begin{array}{l}.006 \\
(.005)\end{array}$ & $\begin{array}{c}-.013^{* *} \\
(.006)\end{array}$ & $\begin{array}{l}.005 \\
(.005)\end{array}$ & $\begin{array}{l}.014 \\
(.011)\end{array}$ & $\begin{array}{c}.049 * * * \\
(.020)\end{array}$ \\
\hline$>10,<=13$ & $\begin{array}{l}.002 \\
(.005)\end{array}$ & $\begin{array}{l}-.004^{*} \\
(.002)\end{array}$ & $\begin{array}{l}.005^{*} \\
(.003)\end{array}$ & $\begin{array}{l}-.004^{*} \\
(.002)\end{array}$ & $\begin{array}{l}.003 \\
(.005)\end{array}$ & $\begin{array}{l}-.009 \\
(.010)\end{array}$ \\
\hline
\end{tabular}

$* * *, * *, *$ : represent significance at $1 \%, 5 \%$ and $10 \%$ confidence levels, respectively. 
Table 10: Marginal Effects - Different Age Groups

\begin{tabular}{|c|c|c|c|c|c|c|}
\hline \multirow[t]{2}{*}{ Birth Year } & \multicolumn{2}{|c|}{1965 and After } & \multicolumn{2}{|c|}{ Between 1956 and 1965} & \multicolumn{2}{|c|}{ Before 1956} \\
\hline & Welfare & Work & Welfare & Work & Welfare & Work \\
\hline $\begin{array}{l}\text { Effects of Policy Change } \\
(\text { Two or More Kids }) \times \\
(\text { Year }>1993)\end{array}$ & $\begin{array}{l}-.030 \\
\quad(.036)\end{array}$ & $\begin{array}{l}.065 \\
(.041)\end{array}$ & $\begin{array}{c}-.066^{* * *} \\
(.025)\end{array}$ & $\begin{array}{l}.069^{*} \\
(.037)\end{array}$ & $\begin{array}{l}-.028 \\
(.022)\end{array}$ & $\begin{array}{c}.077^{* * *} \\
(.041)\end{array}$ \\
\hline $\begin{array}{l}(\text { Time Limit }) \times \\
<5 \text { Years Old }\end{array}$ & $\begin{array}{l}-.017 \\
(.026)\end{array}$ & $\begin{array}{l}.017 \\
(.031)\end{array}$ & $\begin{array}{l}-.027 \\
(.020)\end{array}$ & $\begin{array}{c}.077^{* * *} \\
(.034)\end{array}$ & $\begin{array}{l}-.012 \\
(.020)\end{array}$ & $\begin{array}{l}.055 \\
(.045)\end{array}$ \\
\hline$>5,<=10$ & $\begin{array}{l}.066 \\
(.065)\end{array}$ & $\begin{array}{l}-.037 \\
(.078)\end{array}$ & $\begin{array}{l}-.012 \\
(.030)\end{array}$ & $\begin{array}{l}-.015 \\
(.048)\end{array}$ & $\begin{array}{l}-.017 \\
(.031)\end{array}$ & $\begin{array}{l}.057 \\
(.069)\end{array}$ \\
\hline$>10,<=13$ & $\begin{array}{c}.675^{* * *} \\
(.120)\end{array}$ & $\begin{array}{c}-.342^{* *} \\
(.169)\end{array}$ & $\begin{array}{l}.099 \\
(.075)\end{array}$ & $\begin{array}{l}.067 \\
(.077)\end{array}$ & $\begin{array}{l}.011 \\
(.037)\end{array}$ & $\begin{array}{l}.018 \\
(.076)\end{array}$ \\
\hline $\begin{array}{l}(\text { Work Requirement }) \times \\
<5 \text { Years Old }\end{array}$ & $\begin{array}{l}.026 \\
(.027)\end{array}$ & $\begin{array}{l}.009 \\
(.030)\end{array}$ & $\begin{array}{l}-.001 \\
(.023)\end{array}$ & $\begin{array}{l}-.023 \\
(.036)\end{array}$ & $\begin{array}{l}-.023 \\
(.019)\end{array}$ & $\begin{array}{l}-.034 \\
(.049)\end{array}$ \\
\hline$>5,<=10$ & $\begin{array}{l}.019 \\
(.061)\end{array}$ & $\begin{array}{l}-.053 \\
(.076)\end{array}$ & $\begin{array}{l}.036 \\
(.034)\end{array}$ & $\begin{array}{l}.068 \\
(.045)\end{array}$ & $\begin{array}{l}.042 \\
(.039)\end{array}$ & $\begin{array}{l}-.035 \\
(.074)\end{array}$ \\
\hline$>10,<=13$ & $\begin{array}{c}-.193^{* * * *} \\
(.063)\end{array}$ & $\begin{array}{l}.130 \\
(.264)\end{array}$ & $\begin{array}{l}-.002 \\
(.056)\end{array}$ & $\begin{array}{l}-.143 \\
(.092)\end{array}$ & $\begin{array}{l}.053 \\
(.048)\end{array}$ & $\begin{array}{l}-.069 \\
(.092)\end{array}$ \\
\hline $\begin{array}{l}\text { Sample Proportion } \\
\text { Observations }\end{array}$ & $\begin{array}{c}.24 \\
29,567\end{array}$ & .54 & $\begin{array}{c}.14 \\
44,695\end{array}$ & .65 & $\begin{array}{c}.09 \\
71,029\end{array}$ & .66 \\
\hline
\end{tabular}

***, **, *: represent significance at $1 \%, 5 \%$ and $10 \%$ confidence levels, respectively. 
Table 11: Robustness Check: Bivariate Probit and Linear Probability Model Estimates

\begin{tabular}{|c|c|c|c|c|}
\hline & \multicolumn{2}{|c|}{ Bivariate Probit } & \multicolumn{2}{|c|}{ Linear Probability } \\
\hline & Welfare & Work & Welfare & Work \\
\hline $\begin{array}{l}(\text { Two or More Kids }) \times \\
(\text { Year }>1993)\end{array}$ & $\begin{array}{c}-.026^{* *} \\
(.013)\end{array}$ & $\begin{array}{c}.053^{* * *} \\
(.022)\end{array}$ & $\begin{array}{c}-.046^{* * *} \\
(.006)\end{array}$ & $\begin{array}{c}.020 * * * \\
(.006)\end{array}$ \\
\hline $\begin{array}{l}(\text { Time Limit }) \times \\
<5 \text { Years Old }\end{array}$ & $\begin{array}{c}-.026^{* * *} \\
(.010)\end{array}$ & $\begin{array}{c}.070^{* * *} \\
(.020)\end{array}$ & $\begin{array}{c}-.021^{* * *} \\
(.004)\end{array}$ & $\begin{array}{c}.024^{* * *} \\
(.005)\end{array}$ \\
\hline$>5,<=10$ & $\begin{array}{l}-.007 \\
(.019)\end{array}$ & $\begin{array}{l}-.020 \\
(.034)\end{array}$ & $\begin{array}{c}-.017^{* * *} \\
(.007)\end{array}$ & $\begin{array}{c}-.015^{* *} \\
(.008)\end{array}$ \\
\hline$>10,<=13$ & $\begin{array}{l}.056 \\
(.036)\end{array}$ & $\begin{array}{l}.036 \\
(.049)\end{array}$ & $\begin{array}{l}.002 \\
(.010)\end{array}$ & $\begin{array}{l}-.009 \\
(.012)\end{array}$ \\
\hline $\begin{array}{l}\text { (Work Requirement) } \\
<5 \text { Years Old }\end{array}$ & $\begin{array}{l}-.004 \\
(.011)\end{array}$ & $\begin{array}{l}.011 \\
(.019)\end{array}$ & $\begin{array}{l}.009^{* *} \\
(.004)\end{array}$ & $\begin{array}{c}-.019 * * * \\
(.004)\end{array}$ \\
\hline$>5,<=10$ & $\begin{array}{l}.030 \\
(.021)\end{array}$ & $\begin{array}{l}.044 \\
(.034)\end{array}$ & $\begin{array}{c}.018^{* * *} \\
(.007)\end{array}$ & $\begin{array}{c}.032^{* * *} \\
(.008)\end{array}$ \\
\hline$>10,<=13$ & $\begin{array}{l}.010 \\
(.030)\end{array}$ & $\begin{array}{l}-.095^{*} \\
(.050)\end{array}$ & $\begin{array}{l}.020^{* *} \\
(.011)\end{array}$ & $\begin{array}{l}.018 \\
(.012)\end{array}$ \\
\hline
\end{tabular}

$* * *, * *, *$ : represent significance at $1 \%, 5 \%$ and $10 \%$ confidence levels, respectively. 
Table 12: Identification Check: Coefficient Estimates Comparing Two and Three and More Children

\begin{tabular}{|c|c|c|}
\hline & Welfare Use & Work \\
\hline \multicolumn{3}{|c|}{$\begin{array}{l}\text { Effects of Policy Changes } \\
\text { (More Than Two Kids) } \times\end{array}$} \\
\hline 1989 & $\begin{array}{c}-.467 \\
(1.091)\end{array}$ & $\begin{array}{c}-1.789^{* *} \\
(.870)\end{array}$ \\
\hline 1990 & $\begin{array}{l}.550 \\
(.736)\end{array}$ & $\begin{array}{l}.437 \\
(.741)\end{array}$ \\
\hline 1991 & $\begin{array}{l}-.410 \\
(.478)\end{array}$ & $\begin{array}{l}1.187 \\
(.724)\end{array}$ \\
\hline 1992 & $\begin{array}{l}-.349 \\
(.341)\end{array}$ & $\begin{array}{l}1.537^{* * *} \\
(.556)\end{array}$ \\
\hline 1994 & $\begin{array}{l}-.342 \\
(.367)\end{array}$ & $\begin{array}{l}.275 \\
(.632)\end{array}$ \\
\hline 1995 & $\begin{array}{l}-.499 \\
(.470)\end{array}$ & $\begin{array}{l}1.060 \\
(.820)\end{array}$ \\
\hline 1996 & $\begin{array}{l}-.603 \\
(.386)\end{array}$ & $\begin{array}{l}.755 \\
(.553)\end{array}$ \\
\hline 1997 & $\begin{array}{l}-.658 \\
(.451)\end{array}$ & $\begin{array}{l}.380 \\
(.630)\end{array}$ \\
\hline 1998 & $\begin{array}{l}-5.055^{* * *} \\
(.589)\end{array}$ & $\begin{array}{c}1.585^{* *} \\
(.707)\end{array}$ \\
\hline 1999 & $\begin{array}{l}.132 \\
(.515)\end{array}$ & $\begin{array}{l}.961 \\
(.677)\end{array}$ \\
\hline 2000 & $\begin{array}{c}.682 \\
(.617)\end{array}$ & $\begin{array}{l}1.543 \\
(1.170)\end{array}$ \\
\hline \multicolumn{3}{|l|}{$($ Time Limit $) \times$} \\
\hline$<5$ Years Old & $\begin{array}{l}-.398 \\
(.253)\end{array}$ & $\begin{array}{l}-.103 \\
(.312)\end{array}$ \\
\hline$>5,<=10$ & $\begin{array}{l}.565 \\
(.380)\end{array}$ & $\begin{array}{l}.362 \\
(.481)\end{array}$ \\
\hline$>10,<=13$ & $\begin{array}{l}-.318 \\
(.352)\end{array}$ & $\begin{array}{l}1.510^{* * *} \\
(.502)\end{array}$ \\
\hline \multicolumn{3}{|c|}{ (Work Requirement) $\times$} \\
\hline$<5$ Years Old & $\begin{array}{l}-.127 \\
(.229)\end{array}$ & $\begin{array}{l}-.582 \\
(.435)\end{array}$ \\
\hline$>5,<=10$ & $\begin{array}{c}-1.398^{* * *} \\
\quad(.323)\end{array}$ & $\begin{array}{r}-.802^{*} \\
(.444)\end{array}$ \\
\hline$>10,<=13$ & $\begin{array}{l}-.041 \\
(.370)\end{array}$ & $\begin{array}{c}-1.964^{* * *} \\
(.531)\end{array}$ \\
\hline
\end{tabular}

$* * *, * *, *$ : represent significance at $1 \%, 5 \%$ and $10 \%$ confidence levels, respectively. 
Figure 1: Welfare and Work Decisions of SIPP Low-Skilled Single Mothers

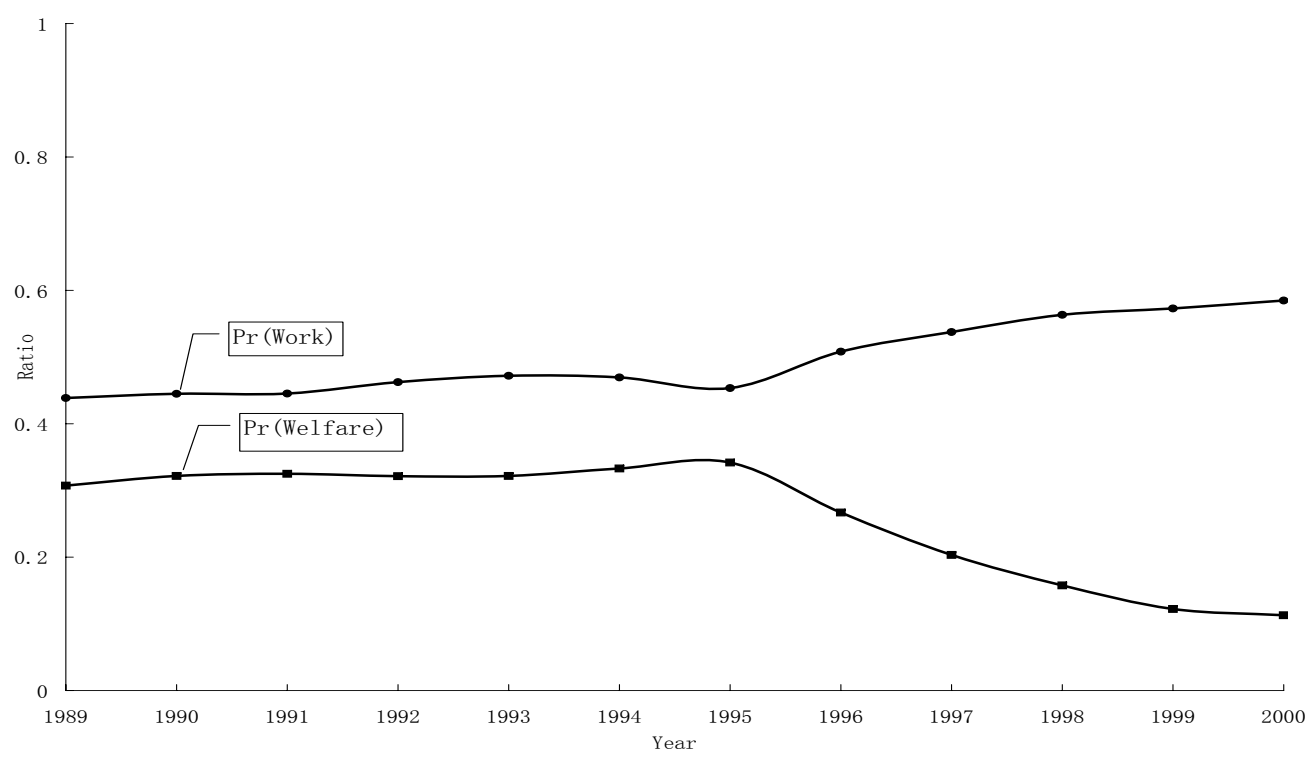

(a) AFDC/TANF Use and Employment

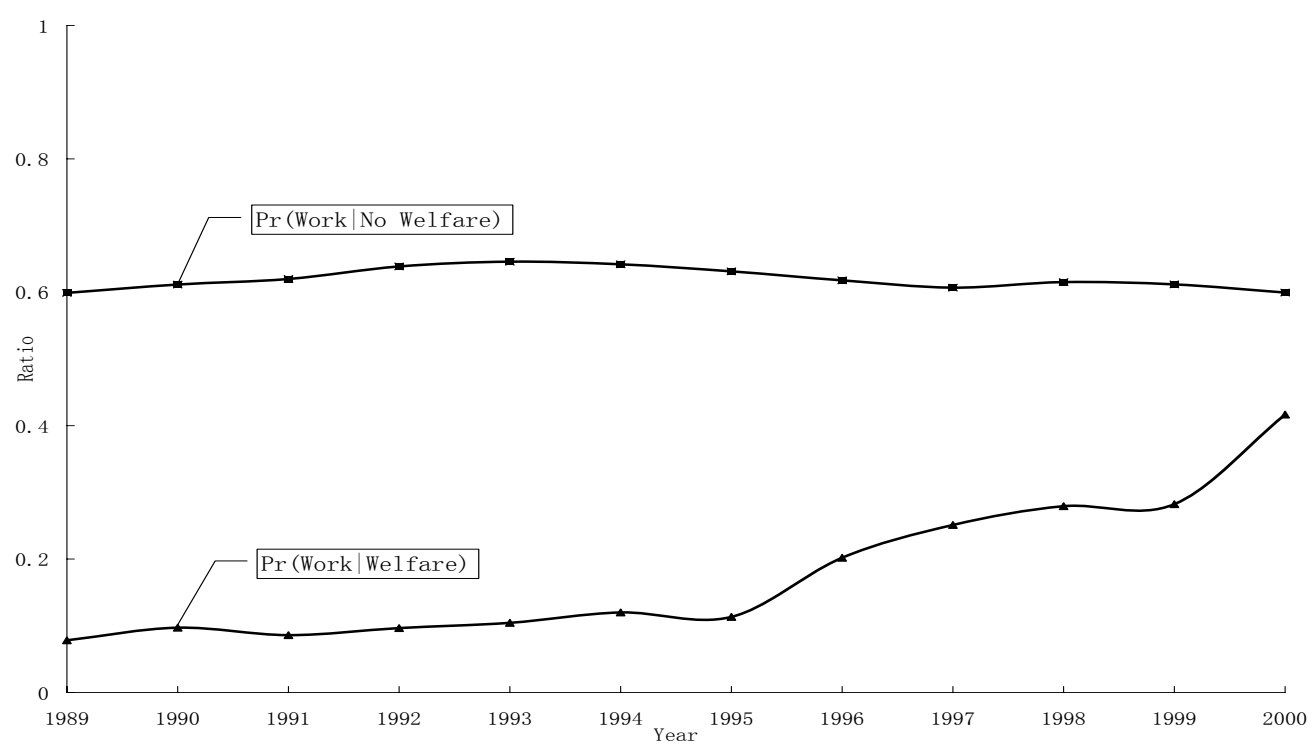

(b) Work Decisions Given Welfare Status

\section{Appendix}




\section{A.1 Linear Probability Model}

It is straightforward to estimate the joint probability of welfare use and work decisions by using a nonlinear probability specification, such as the multinomial model. However, there are two important disadvantages of nonlinear probability models. First, the marginal effects of explanatory variables on probabilities are nonlinear functions of the estimated coefficients. Not only is the interpretation not straightforward, but the calculation time increases exponentially with sample size. Second, and more importantly, there is not yet an empirical non-linear probabilistic model that consistently estimates a mother's decisions accounted for the mother's fixed-effect. Due to these restrictions, the linear probability model is the most adopted econometric specification in previous studies (see Table 3).

Since a linear probability model is binary, it estimates the "marginal" probability of either welfare use or work. As a result, we have to specify two linear probabilities for each of a single mother's welfare use and work decisions. One issue arising from estimating a marginal probability model is that we will not be able to know the compositional change between mothers' four alternatives due to either welfare time limits or the EITC expansion.

Since the marginal probability of making one decision, say welfare use, depends also on the other decision, in this case, work, ignoring one decision when estimating the other using a binary probability model will induce an omitted-variable problem and bias the estimator. Most previous studies do not deal with this simultaneity issue in their binary probabilistic specifications, with the notable exception of Meyer and Rosenbaum (2001).

Considering the above concerns, I specify a linear probability model of a single mother's decision, including the marginal probability of a mother's one decision as explanatory variable in the likelihood of the other decision, which will be discussed below. The model 
of welfare use can be described as follows. Work decision is defined similarly.

$$
\begin{aligned}
W_{i s t}^{*} & =\beta_{0}+\beta_{1} \sum_{l=1989 \_01}^{2000 \_12} D_{i, 2+\mathrm{kids}, l} D_{l}+\sum_{l=1989 \_01}^{2000 \_12} \sum_{j=1}^{3} \beta_{2 j} D_{i, j, l} D_{i, \text { timelimit }, l}+ \\
& +\sum_{l=1989 \_01}^{2000 \_12} \sum_{k=1}^{9} \beta_{3 k} D_{i, \mathrm{kids}=k, l}+\sum_{s=1}^{S} \beta_{4 s} D_{i s t}+\sum_{y=1989}^{2000} \beta_{5 y} D_{y}+\beta_{6} \sum_{l=1989 \_01}^{2000 \_12} D_{i, \text { timelimit }, l} \\
& +\beta_{7} \sum_{l=1989 \_01}^{2000 \_12} D_{i, \text { workreq }, l}+\gamma X_{i s t}+\epsilon_{i}^{W},
\end{aligned}
$$

The definitions of variables follow that in Equation A.1. Also, $\operatorname{Pr}\left(H_{i s t} \mid X_{i s t}, D\right)$ is the probability of work given all the observed characteristics of mothers; and $\epsilon_{i s t}$ captures the unobserved factors that vary across individual, state, and yearly. $\operatorname{Pr}\left(H_{i s t} \mid X_{i s t}, D\right)$ in the welfare likelihood estimation will be estimated by a mother's random-effect probit models. The rationale is that random-effect probit estimator is nonlinear in the observed variables and $\epsilon_{i s t}$. Therefore, the effect of $\delta$ can be identified.

An Ordinary Least Square (OLS) estimator is biased because $\epsilon_{i s t}$ is correlated with the observed explanatory variables. For instance, a state that set a time limit before PRWORA (observed variable), may also be less generous to its support of low-income families (unobserved variable), and in turn, poor families residing in this state are also less likely to be on welfare. Also, single mothers with mental or physical problems (unobserved) may be more likely to be on welfare, while receiving less education (observed). Another important issue regarding the welfare use is the effect of business cycles. For example, it is well known that the recession in the early 1990s is an important cause for the sudden surge in welfare use during that same period of time.

These factors create an unobserved heterogeneity issue. I assume the unobserved factor $\epsilon_{i s t}$ is separable by individual, state, and year:

$$
\epsilon_{i s t}=\sigma_{i}+\mu_{s}+\nu_{t}+u
$$

where $u$ is an i.i.d. random disturbance. $\sigma_{i}, \mu_{s}$, and $\nu_{t}$ can be controlled by adding individual (mother), state, and year fixed-effect dummy variables, respectively. 